\title{
molecules
}

ISSN 1420-3049

www.mdpi.com/journal/molecules

Article

\section{Multifaceted Strategy for the Synthesis of Diverse 2,2'-Bithiophene Derivatives}

\author{
Stanisław Krompiec $^{1, *}$, Michał Filapek ${ }^{1}$, Iwona Grudzka-Flak ${ }^{1}$, Aneta Slodek ${ }^{1}$, Sławomir Kula ${ }^{1}$, \\ Jan Grzegorz Malecki ${ }^{1}$, Joanna Malarz ${ }^{1}$, Grażyna Szafraniec-Gorol ${ }^{1}$, Mateusz Penkala ${ }^{1}$, \\ Ewa Schab-Balcerzak ${ }^{1}$, Marian Paluch ${ }^{2}$, Michał Mierzwa ${ }^{2}$, Marek Matussek ${ }^{1}$, Agata Szlapa ${ }^{1}$, \\ Michał Pajak ${ }^{1}$, Dariusz Blach ${ }^{1}$, Beata Marcol ${ }^{1}$, Witold Danikiewicz ${ }^{3}$, Bartosz Boharewicz ${ }^{4}$, \\ and Agnieszka Iwan 4
}

1 Institute of Chemistry, Faculty of Mathematics, Physics and Chemistry, University of Silesia, Szkolna 9, Katowice 40-007, Poland; E-Mails: filus.lc@interia.pl (M.F.);

iwonagrudzka@gmail.com (I.G.-F.); a.slodek@wp.pl (A.S.); kula.slawek@gmail.com (S.K.); gmalecki@us.edu.pl (J.G.M.); joanna.malarz@gmail.com (J.M.); grazyna.szafraniec@wp.pl (G.S.-G.); mateusz.penkala@us.edu.pl (M.P.); ewa.schab-balcerzak@us.edu.pl (E.S.-B.); marmat89@interia.pl (M.M.); agataszlapa@o2.pl (A.S.); spider1989@gmail.com (M.P.); dariusz2lo@o2.pl (D.B.); beata_marcol@wp.pl (B.M.)

2 Institute of Physics, Faculty of Mathematics, Physics and Chemistry, University of Silesia, Uniwersytecka 4, Katowice 40-007, Poland; E-Mails: marian.paluch@us.edu.pl (M.P.); michal.mierzwa@us.edu.pl (M.M.)

3 Polish Academy of Science, Institute of Organic Chemistry Kasprzaka 44/52, PO Box 58, Warsaw 01-224, Poland; E-Mail: witold.danikiewicz@icho.edu.pl

4 Electrotechnical Institute, Division of Electrotechnology and Materials Science, M. Skłodowskiej-Curie 55/61, Wrocław 50-369, Poland; E-Mails: b.boharewicz@iel.wroc.pl (B.B.); a.iwan@iel.wroc.pl (A.I.)

* Author to whom correspondence should be addressed; E-Mail: stanislaw.krompiec@us.edu.pl; Tel.: +48-32-359-1646; Fax: +48-32-259-9978.

Academic Editor: Derek J. McPhee

Received: 13 January 2015 / Accepted: 26 February 2015 / Published: 12 March 2015

Abstract: New catalytically or high pressure activated reactions and routes, including coupling, double bond migration in allylic systems, and various types of cycloaddition and dihydroamination have been used for the synthesis of novel bithiophene derivatives. Thanks to the abovementioned reactions and routes combined with non-catalytic ones, new 
acetylene, butadiyne, isoxazole, 1,2,3-triazole, pyrrole, benzene, and fluoranthene derivatives with one, two or six bithiophenyl moieties have been obtained. Basic sources of crucial substrates which include bithiophene motif for catalytic reactions were 2,2'-bithiophene, gaseous acetylene and 1,3-butadiyne.

Keywords: bithiophene derivatives; coupling; cycloaddition; high pressure; homogeneous catalysis; isomerization; PTC

\section{Introduction}

Compounds containing thiophene, bithiophene or oligothiophene motifs are particularly popular because they are used in various fields of science and technology, ranging from organic chemistry and synthesis to material science, technology, medicine and pharmaceutical science. Therefore, new structures containing the abovementioned motifs are still being synthesized and the possibilities of their practical application intensively tested. Various organic and organometallic systems containing thiophene, bithiophene or oligothiophene moieties (and other essential structural elements, i.e., highly conjugated aromatic and heteroaromatic systems, coordinated metal centers, diimide or triphenylamine moiety and others) are used in organic electronics [1-4] and are still intensively investigated in OLED [1-4], organic field-effect transistor [1,5] and solar cell [1,6,7] technology.

As far as examples of application in medicine and pharmaceutical science are concerned, 5-(4-hydroxyphenyl)-5'-dicyanoethenyl-2,2'-bithiophene was tested as a marker of cell lesions in Alzheimer's disease [8]. Moreover, 5'-mercapto-2,2'-bithiophene-5-carboxylic acid was tested as a potential biosensor detecting antigen-antibody connection [9], and a series of 5-(E)-styryl-2,2'bithiophenes were tested as potential $\beta$-amyloid probes [10]. The starting substances for the synthesis of these compounds are simple derivatives of thiophene, bithiophene or oligothiophene substituted by $\mathrm{Li}, \mathrm{Br}, \mathrm{I}, \mathrm{C} \equiv \mathrm{CH}, \mathrm{MgCl}, \mathrm{SnBu} 3, \mathrm{~B}(\mathrm{OH})_{2}, \mathrm{~B}(\mathrm{OR})_{2}$, or $\mathrm{ZnCl}$, which facilitate the chemical modification of their structures. The bithiophene derivatives, such as bromo- [11,12] and iodobithiophene [13-15], 5-trialkylstannyl-2,2'-bithiophene [16], 5-ethynyl-2,2'-bithiophene [17], 2,2'-bithiophene-5-boronic acid and its esters [12], and (2,2'-bithiophen-5-yl)magnesium bromide, are frequently used [18]. The abovementioned thiophene derivatives were obtained in the catalytic processes, mostly with the aid of transition metal catalysts.

However, in many cases such catalytic systems are inactive due to strong coordination of the substrate by a transition metal catalytic center [19]. This fact ought to be taken into consideration when planning catalytic systems to be used for transformations of strongly coordinated reagents, for instance thiophene or oligothiophene [19]. There are a number of stable neutral and cationic transition metal ( $\mathrm{Cr}, \mathrm{Ru}, \mathrm{Ir}, \mathrm{Rh}, \mathrm{Mn}, \mathrm{Re}, \mathrm{Ti}, \mathrm{Cu}, \mathrm{Fe}$ etc.) complexes with thiophene. The issue of transition metal complexation with thiophene and oligothiophenes has been intensively studied in view of the hydrodesulfurization (HDS) process [20]. Thiophene coordinates transition metals in many ways, but the most common are the $\eta^{1}-S, \eta^{1}-C$, and $\eta^{5}$ - coordination modes [21,22], and furthermore, it forms neutral complexes with Re and $\mathrm{Mn}$, involving $\mathrm{C}$-, S- and $\pi$-coordinated ligands [23]. Moreover, it forms stable cationic complexes, e.g., $\left[\mathrm{Mn}(\mathrm{CO})_{3}\left(\eta^{5}\right.\right.$-thiophene $\left.)\right]\left[\mathrm{BF}_{4}\right]$, which precursor is $\left[\mathrm{Mn}(\mathrm{CO})_{5} \mathrm{Br}\right]$. 
In addition, exchange of $\mathrm{CO}$-ligand to $\eta^{5}$-thiophene in the reaction of $\left[\mathrm{Cr}(\mathrm{CO})_{6}\right]$ with various thiophene derivatives $\left[\mathrm{Cr}(\mathrm{CO})_{3}\left(\eta^{5}\right.\right.$-substituted-thiophenes)] took place [24]. Furthermore, reaction of $\left[\mathrm{RuCl}_{2}(p \text {-cymene })\right]_{2}$ with tetramethylthiophene resulted in a very stable [(tetramethyl-thiophene) $\left.\mathrm{RuCl}_{2}\right]_{2}$ complex, indicating that thiophene coordinates a $\mathrm{Ru}$ atom stronger than $p$-cymene [25]. The above analysis indicates that strong coordination of a transition metal with thiophene and oligothiophene may interfere with some reactions involving substrates containing a thiophene moiety.

The synthesis of pyridine [26], bipyridine, terpyridine [27], carbazole [28] and benzene [29] derivatives containing 2-thienyl, 3,4-methylenedioxothien-2-yl and/or 2,2'-bithiophen-5-yl moieties in Stille cross-coupling reactions has been recently reported. Herein, we present a novel strategy for the synthesis of many bithiophene derivatives via new catalytically or high pressure activated reactions and catalytic routes combined with non-catalytic ones (Scheme 1).

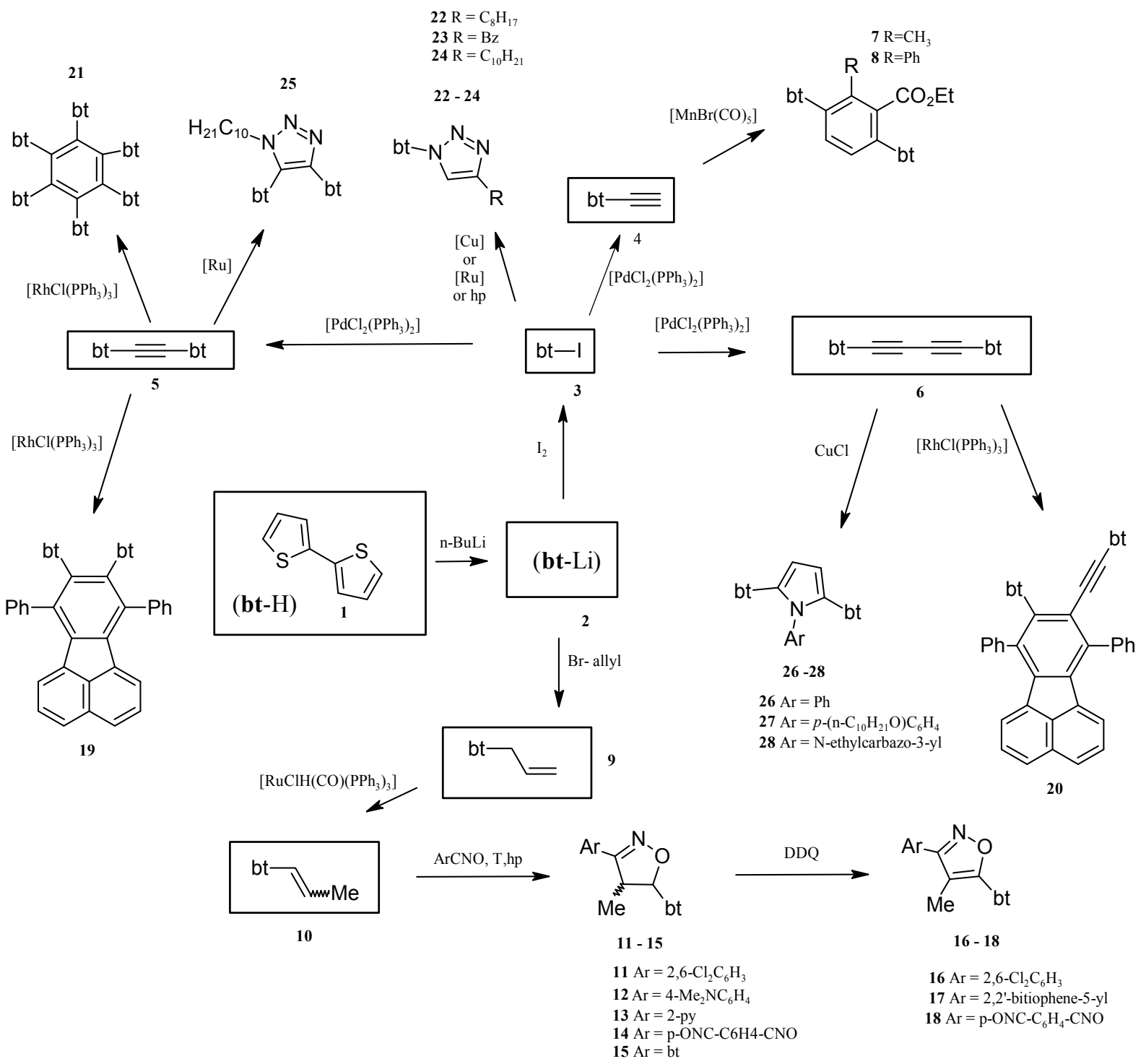

Scheme 1. Synthetic pathways to various 2,2'-bithiophene derivatives from 2,2'-bithiophene (bt-H). Compounds marked as 7, 8, 10-28 are new. 
The substrates containing a bithiophene motif were prepared from commercially available 2,2'-bithiophene, which during the first stage was lithiated according to the procedure developed by us (Scheme 1). Next, the 5-lithio-2,2'-bithiophene ("the first generation" substrate) was converted into 5-iodo- and 5-allyl-2,2'-bithiophenes and in situ into 5-azido-2,2'-bithiophene ("the second generation" substrates). In the subsequent step, the abovementioned compounds were catalytically transformed into 5-ethynyl-2,2'-bithiophene, 1,2-bis(2,2'-bithiophene-5-yl)acetylene, 5-(1-propenyl)-2,2'-bithiophene, and 1,4-bis(2,2'-bithiophene-5-yl)buta-1,3-diyne ("the third generation" substrates).

It is worth noting that the reactions leading to new 2,2'-bithiophene derivatives have not been reported so far (or are significantly improved). Since our work is a multifaceted one, i.e., it concerns a series of different reactions, relevant literature is presented in each subsection.

\section{Results and Discussion}

\subsection{Synthesis of Substrates (for Catalytic Reactions) Containing 2,2'-Bithiophene Moiety from 2,2'-Bithiophene}

The initial step for the strategy presented in Scheme 1 was selective synthesis of 5-lithio-2,2'bithiophene (2). Compound 2 was then used for a direct or multi-step preparation of the following compounds: 5-iodobithiophene (3), 5-ethynyl-2,2'-bithiophene (4), 1,2-bis(2,2'-bithiophen-5-yl)ethyne (5), and 1,4-bis(2,2'-bithiophen-5-yl)-1,3-butadiyne (6), 5-allyl-2,2'-bithiophene (9), 5-(1-propenyl)-2,2'bithiophene (10) The selective synthesis of 2 via reaction of 2,2'-bithiophene with $n$-BuLi, and then synthesis of $\mathbf{3}$ and $\mathbf{4}$ was reported in detail in our previous paper [29] and patents [30,31]. Despite the fact that the synthesis of 5-iodo-2,2'-bithiophene (3) was highly selective and less than $0.5 \%$ of 5,5'-diiodo-2,2'-bithiophene was obtained, it was possible to obtain monocrystals of 5,5'-diiodo-2,2'bithiophene which structure was determined by X-ray diffraction (Supplementary Table S3 in Supporting Information). From the practical point of view, it is very important that any bithiophene lithiation product used for the synthesis of $\mathbf{3}, \mathbf{4}, \mathbf{5}, \mathbf{6}, \mathbf{9}$ and $\mathbf{1 0}$, contains $80 \%$ of 2 , less than $0.5 \%$ of dilithiobithiophene, and $\sim 19.5 \%$ unreacted bithiophene. Low concentration of the dilithioderivative was crucial for the selectivity and yields of subsequent reactions, including the catalytic ones. In particular, thanks to the abovementioned selectivity, the formation of polymeric products was not observed in practice. Additionally, unreacted bithiophene turned out to be inert, did not disturb catalytic reactions, and was finally recovered in the pure product separation procedure.

Compounds 5 and $\mathbf{6}$ were synthesized from gaseous acetylene or gaseous butadiyne using new methods (Scheme 2) [14,15]. Previously, ArC $\equiv$ CAr type compounds, including 1,2-bis(2-thienyl)acetylene, were obtained [32] using acetylene generated in situ from $\mathrm{CaC}_{2}$ and $\mathrm{H}_{2} \mathrm{O}$ in $\mathrm{MeCN}$ [11]. Compound 5 was previously obtained via three-step synthesis from iodobithiophene (coupling of $\mathbf{3}$ with TMS, distillation to 4 and finally coupling 3 with 4) [33]. Compound 6 was synthesized via homocoupling of 4 in the presence of $\mathrm{CuCl} / \mathrm{TMEDA}$ [34]. Additionally, various $\mathrm{ArC} \equiv \mathrm{CC} \equiv \mathrm{CAr}$ type compounds (but not 6) were synthesized from ArI via Sonogashira-Glaser coupling [35]. On the other hand, the synthesis of compounds $\mathrm{ArC} \equiv \mathrm{CC} \equiv \mathrm{CAr}$ type from gaseous butadiyne is unknown.

The strategy of synthesis of some bithiophene-motif containing substrates from gaseous acetylene or gaseous butadiyne corresponds well with observed butadiyne rebirth in chemical technology [36]. It 
is well known that butadiyne is created as a side product of acetylene production [36]. Due to this fact, the application of the both gaseous reagents in our strategy, instead of protected forms of these compounds, is rational and modern. Additionally, commercially available trimethylsilylacetylene used by us for the synthesis of 5-ethynyl-2,2'-bithiophene was also prepared from acetylene [37].

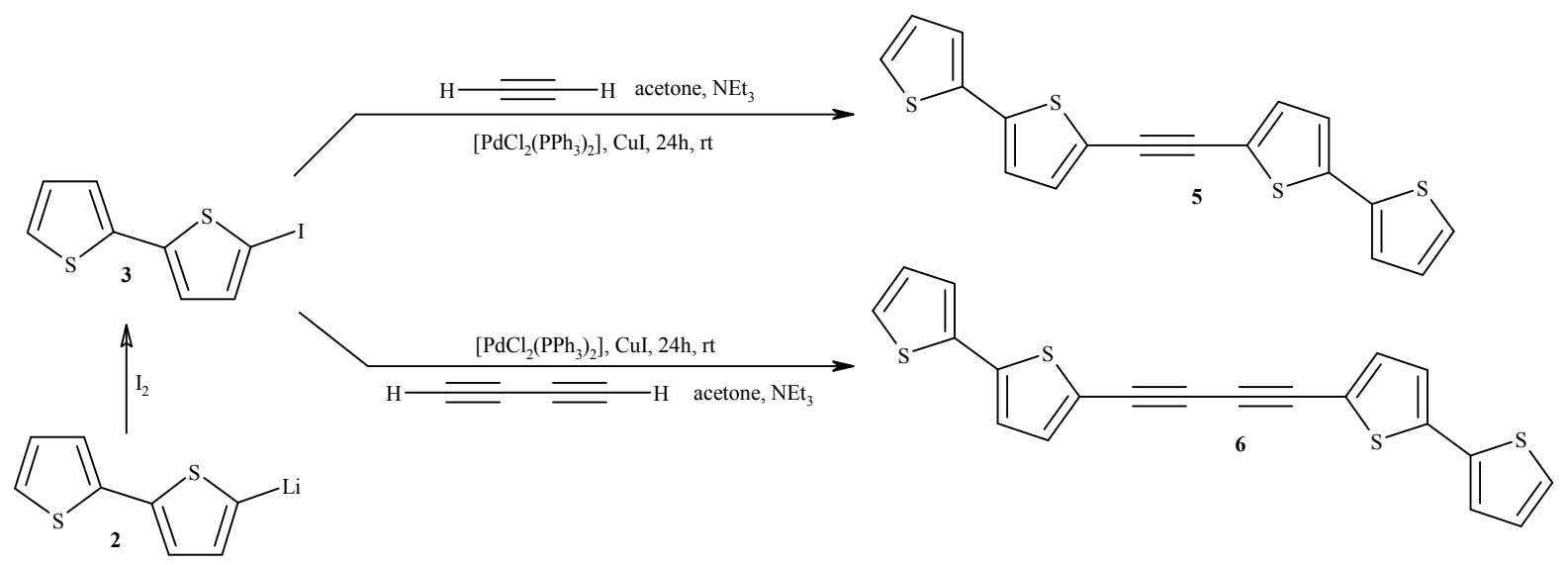

Scheme 2. Synthesis of 5-iodo-2,2'-bithiophene (3), 1,2-bis(2,2'-bithiophen-5-yl)ethyne (5), and 1,4-bis(2,2'-bithiophen-5-yl)-1,3-butadiyne (6). The generation of buta-1,3-diyne has been previously described [11].

In order to improve the yield of 5 and $\mathbf{6}$ we applied a cascade consisting of three reactors. The reactions were carried out in acetone due to a high solubility of acetylene and butadiyne therein. Other authors have used $\mathrm{MeCN}$ as solvent [32], but MeCN appears to be a much worse solvent (the solubility of acetylene therein is much lower), and in addition it is toxic. Gaseous acetylene (generated from $\mathrm{CaC}_{2}$ [34] or more conveniently supplied from a bottle gas) and butadiyne (generated from 1,4-dichloro-2-butyne) were dried before the introduction into the reaction system and additionally dispersed with a stream of argon. It is of particular importance in the case of butadiyne for safety reasons (high concentrated butadiyne is explosive). Moreover, in the procedure leading to 5 $\left[\mathrm{PdCl}_{2}\left(\mathrm{PPh}_{3}\right)_{2}\right]$ was applied, which was much more effective than $\mathrm{Pd}(\mathrm{OAc})_{2}+\mathrm{PPh}_{3}$ catalytic system used by Chuentragool et al. in the synthesis of 1,2-bis(2-thienyl)acetylene [32]. Compound 6 was obtained as yellow crystals and its structure was confirmed using X-ray crystallography (Table 2 in Supporting Information). The $\left[\mathrm{PdCl}_{2}\left(\mathrm{PPh}_{3}\right)_{2}\right] / \mathrm{CuI}$ catalytic system appeared to be more effective and convenient (due to its stability and price) than $\left[\mathrm{Pd}\left(\mathrm{PPh}_{3}\right)_{4}\right]$ used by McCormick et al., in the synthesis of different $\mathrm{ArC} \equiv \mathrm{CC} \equiv \mathrm{CAr}$ from 1,4-bis(trimethylsilyl)-1,3-butadiyne [38].

Additionally, a new method of preparation of 6 via homocoupling of 5-ethynyl-2,2'-bithiophene (4) in the presence of ethyl iodide, catalyzed by $\mathrm{CuI} /\left[\mathrm{PdCl}_{2}\left(\mathrm{PPh}_{3}\right)_{2}\right]$ was developed (Scheme 3). This method turned out to be very simple and effective (isolated yield was 97\%).

It was found that the absence of alkyl iodide or bromide resulted in extremely low yield (approximately 10\%). In addition, the influence of different alkyl bromides and iodides on the yield of this reaction was tested. It was confirmed that the yield of homocoupling depends on the type of the halide as follows: decyl bromide (60\%), ethyl bromide (70\%), decyl iodide $(80 \%)$, and ethyl iodide (97\%). Moreover, no heterocoupled products of reaction of alkyl halides with 5-ethynyl-2,2'-bithiophene (to bt-三-R) were observed. 


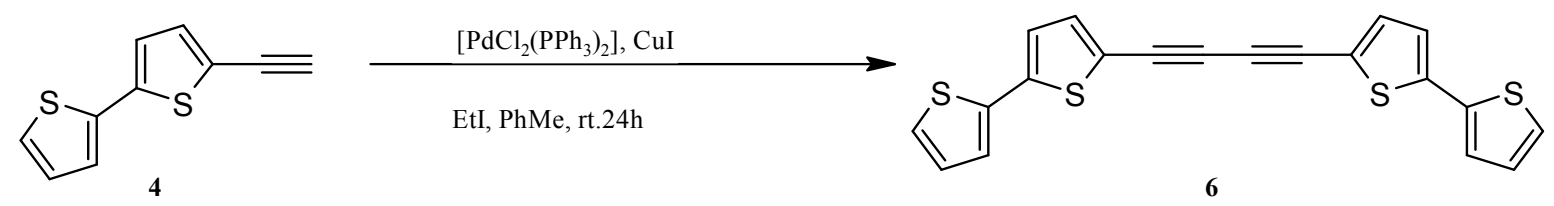

Scheme 3. Homocoupling of 5-ethynyl-2,2'-bithiophene (4) to 1,4-bis(2,2'-bithiophen-5yl)-buta-1,3-diyne (6) in the presence of ethyl iodide mediated by $\mathrm{CuI} /\left[\mathrm{PdCl}_{2}\left(\mathrm{PPh}_{3}\right)_{2}\right]$.

\subsection{Benzene Derivatives with Two bt Moieties Prepared via Manganese-Catalyzed Reaction}

We synthesized 1,4-bis(2,2'-bithiophen-5-yl)-2-methyl-3-etoxycarbonylobenzene (7) and 1,4-bis(2,2'-bithiophen-5-yl)-2-phenyl-3-etoxycarbonylobenzene (8) from 4 and ethyl acetoacetate or benzoylacetate via $\left[\mathrm{MnBr}(\mathrm{CO})_{5}\right]$-catalyzed dehydrative $[2+2+2]$ cycloaddition (Scheme 4).

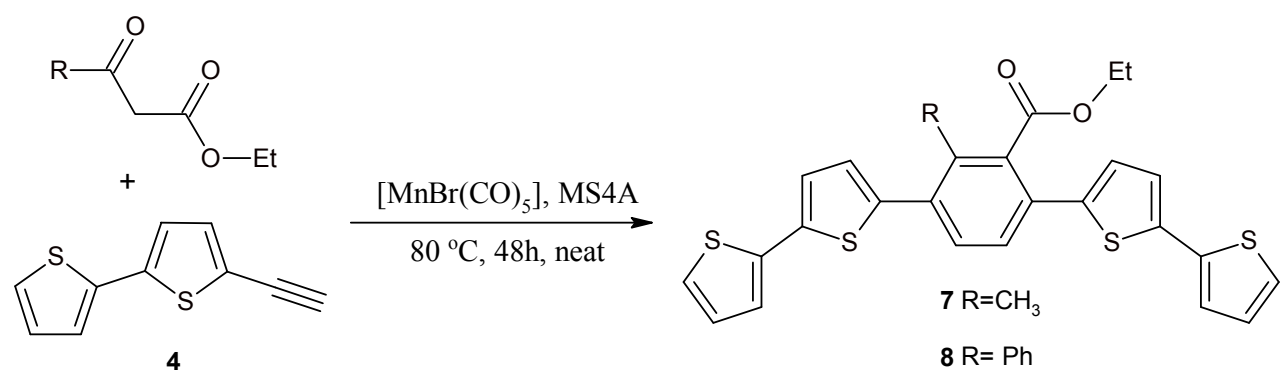

Scheme 4. Synthesis of 1,4-bis(2,2'-bithiophen-5-yl)-2-methyl-3-ethoxycarbonylbenzene (7) and 1,4-bis(2,2'-bithiophen-5-yl)-2-phenyl-3-ethoxycarbonylbenzene (8) via manganesecatalyzed reactions of acetyl- or benzoylacetate with 5-ethynyl-2,2'-bithiophene (4).

The manganese-catalyzed dehydrative [2+2+2] cycloaddition of 1,3-dicarbonyl compounds to terminal alkynes leading to 2,3,6-trisubstituted methyl or ethyl benzoate is known from the literature. However, heteroaromatic substituents are unknown [39-41]. A slight modification of this method allowed us to obtain compounds 7 and $\mathbf{8}$ with electron-rich heteroaromatic substituents such a 2,2'-bithiophen-5-yl. We did not observe any desulfurization side reactions or other transformations of the bithiophene systems, even though the catalytic reactions (using $\mathrm{Mn}, \mathrm{Pd}, \mathrm{Rh}, \mathrm{Ru}$, and $\mathrm{Cu}$ complexes) were carried out at high temperatures. However, the procedures applied by us for the synthesis of $\mathbf{7}$ and $\mathbf{8}$ did not cause the deactivation of the catalytic system. Due to this fact, one should assume that the reaction with 5-ethynyl-2,2'-bithiophene proceeds according to the mechanism proposed for other terminal alkynes [39-41].

\subsection{Isoxazolines With bt Motifs}

Five new isoxazolines containing one or two bithienyl moieties were obtained via [Ru]- or 15-crown-5/ $\mathrm{NaOH}$ catalyzed isomerization of 5-allyl-2,2'-bithiophene 9 to 5-(1-propenyl)-2,2'bithiophene and then 1,3-DC of nitrile oxide to $\mathbf{1 0}$ (Scheme 5). The range of reviews on the synthesis of isoxazolines via the addition of nitrile oxides to alkenes is very extensive and includes many monographic reports [42-45], and our papers [46-48]. The methods of preparation of numerous pure, stable nitrile oxides [49] or generated in situ [50,51] have been also described. The synthesis of 
2-allyl-thiophene in the reaction of 2-lithiothiophene (obtained by the lithiation of bithiophene with $n$-BuLi in THF at $-78{ }^{\circ} \mathrm{C}$ ) with allyl bromide has been reported [52,53]. However, our attempts to apply this method to the synthesis of 9 were inefficient due to low regioselectivity (lithiation of bithiophene produced more than 35\% dilithiobithiophene). Moreover, the synthesis of 9 via reaction of 2-thienylmagnesium chloride with allyl bromide was described in the literature [54]. However, our attempts to use this method to obtain 5-allyl-2,2'-bithiophene in the reaction of (2,2'-bithiophen-5-yl)magnesium iodide or bromide with allyl bromide were not successful in spite of testing various reaction conditions and various catalysts $\left(\left[\mathrm{Pd}\left(\mathrm{PPh}_{3}\right)_{4}\right],\left[\mathrm{PdCl}_{2}\left(\mathrm{PPh}_{3}\right)_{2}\right],\left[\mathrm{NiCl}_{2}(\mathrm{dppe})\right],\left[\mathrm{NiCl}_{2}(\mathrm{dppp})\right]\right)$. The application of our procedure of bithiophene lithiation [29] in the hexane-diethyl ether mixture allowed us to obtain high lithiation regioselectivity (less than $0.5 \%$ of the dilithio product). Compound 9 was conveniently and effectively obtained in the reaction of 2 with allyl bromide without the catalyst (Scheme 5). Practically quantitative isomerization of 5-allyl-2,2'-bithiophene $(9)$ to $(E+Z)-5$-(1-propenyl)-2,2'bithiophene (10) (determined by $\left.{ }^{1} \mathrm{H}-\mathrm{NMR}: E / Z=9 / 1\right)$ using $\left[\mathrm{RuClH}(\mathrm{CO})\left(\mathrm{PPh}_{3}\right)_{3}\right]$ was performed. This catalyst is well-known and has been intensively studied by us and used by others $[19,55,56]$. Additionally, the abovementioned isomerization was realized with a new catalytic system, i.e., 15-crown-5/NaOH/PhMe. The latter catalytic system allowed the quantitative transformation of 9 into 1-propenyl derivative $\mathbf{1 0}$ even at room temperature $(E / Z=10 / 1)$. We also verified that this catalytic system is equally efficient in the isomerization of $\mathrm{N}$-allylimidazole to $N$-(1-propenyl)imidazole and allylphenyl sulphide to phenyl-(1-propenyl) sulphide (in each case a mixture of $E$ and $Z$ isomers was formed). The reactions reached equilibrium Qallyl-Q(1-propenyl), where $\mathrm{Q}=1$-imidazolyl or PhS at room temperature within 24h in PhMe. Among the catalysts of crown ether-base type, applied for the double bond migration, only 18-crown-6/t-BuOK (for the isomerization of 1-phenyl-2-aza-1,4-pentadiene) [57] and 18-crown-6/KOH/benzene (for the isomerization of $\mathrm{N}$-allylimidazole, $\mathrm{PhXCH}_{2} \mathrm{CH}=\mathrm{CH}_{2}$, where $\mathrm{X}=\mathrm{O}, \mathrm{S}$, Se and several $\mathrm{ArCH}=\mathrm{NCH}_{2} \mathrm{CH}=\mathrm{CH}_{2}$ ) have been described so far $[46,58]$.

Compound $\mathbf{1 0}$ was used in the synthesis of five new isoxazolines 11-15, containing one or two bithiophene motifs. The compounds 11-15 were obtained via 1,3-DC of two stable $\left(2,6-\mathrm{Cl}_{2} \mathrm{C}_{6} \mathrm{H}_{4} \mathrm{CNO}\right.$ and $p$ - $\left.(\mathrm{ONC})_{2} \mathrm{C}_{6} \mathrm{H}_{4}\right)$, two low stable nitrile oxides (2-pyridinecarbonitrile oxide and $p$-dimethylaminobenzenecarbonitrile oxide) and extremely unstable 2,2'-bithiophen-5-carbonitrile oxide. It is known that sterically hindered nitrile oxides and those containing substituents decreasing the dipole moment of this dipole are stable [59]. The last three oxides (two low stable and one unstable) were generated in situ from the proper oxymoyl chlorides using triethylamine (added dropwise) in order to achieve high concentration of the dipolarophile $(E+Z)-5$-(1-propenyl)-2,2'-bithiophene. However, the dimerization of these oxides, mainly 2,2'-bithiophen-5-carbonitrile oxide, was observed. Therefore, a 3-fold excess of oxymoyl chloride in relation to the dipolarophile was used and consequently, the quantitative conversion of the latter was attained. When the ratio nitrile oxide/dipolarophile $=1 / 1$, the conversion of $\mathbf{1 0}$ was low, e.g., for 2-pyridinecarbonitrile oxide it was $40 \%$ and the $E / Z$ ratio in the unreacted 10, i.e., after 1,3-DC, was significantly different from that for $\mathbf{1 0}$ before 1,3-DC (4/2 and 9/1, respectively). This means that $(E)-(\mathbf{1 0})$ underwent cycloaddition much faster than $(Z)-(\mathbf{1 0})$. We obtained stable 2-pyridine oxymoyl chloride (described in the literature) and 2,2'-bithiophen-5-carbamoyl chloride from the respective oximes in the reaction with NCS in DMF at room temperature via a typical or modified procedure [60]. Interestingly, in the case of the synthesis of 2,2'-bithiophen-5-carbamoyl chloride via the typical procedure ( $\mathrm{NCS}, \mathrm{HCl}$ in $\mathrm{DMF}$ ) [60], chlorination of the bithiophene ring takes 
place. When the procedure was changed, i.e., when $\mathrm{HCl}$ was no longer used as an initiator, the desired oxymoyl chloride was obtained in high yield (95\%) without the chlorination of thiophene ring. Furthermore, the generation of oxides in situ in DMF proceeds at room temperature (2-pyridine- and $p$-dimethylaminobenzenecarbonitrile oxides $)$ and in THF at $-20^{\circ} \mathrm{C}\left(2,2^{\prime}\right.$-bithiophen-5-carbonitrile oxide).

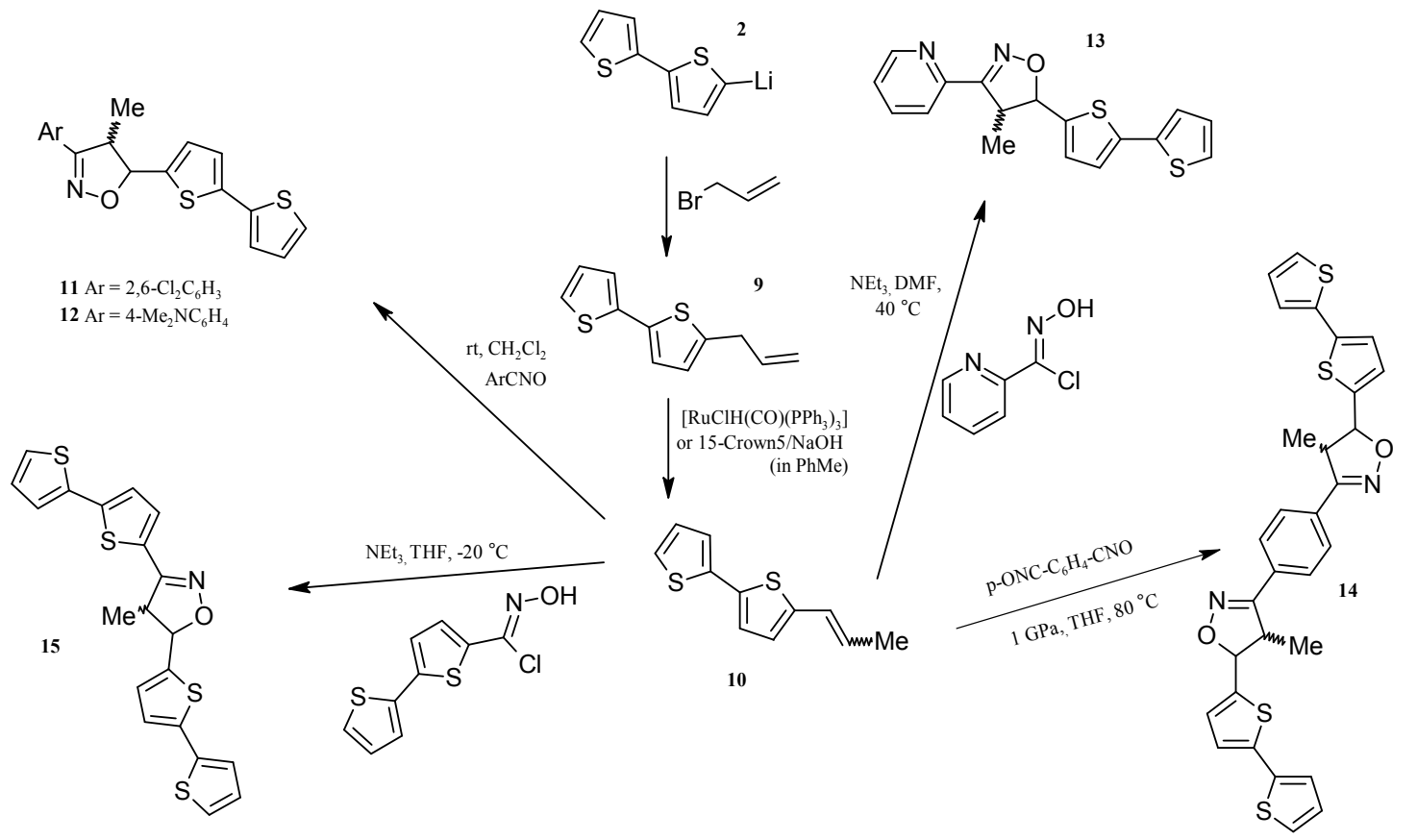

Scheme 5. Synthesis of isoxazolines $(E+Z)-(\mathbf{1 0})$ : cis + trans 3-(2,6-dichlorophenyl-4methyl-5-(2,2'-bithiophen-5-yl)isoxazoline (11); 3-(p-dimethylaminophenyl)-5-(2,2'bithiophen-5-yl)-4-methylisoxazoline (12); 3,5-bis(2,2'-bithiophen-5-yl)-4-methylisoxazoline (15); 5-(2,2'-bithiophen-5-yl)-4-methyl-3-(2-pyridyl)isoxazoline (13); 1,4-bis(5-(2,2'bithiophen-5-ylo)-4-methylisoxazoline-3-ylo)benzene (14).

In the case of the cycloaddition reactions activated by high pressure, it is very important to take into consideration the stability and reactivity of $\mathrm{ArCNO}$, and in addition the solubility of ArCNO in organic solvents (Scheme 5). In the case of terephthaloyldinitrile dioxide, which is a low reactivity oxide, performance of the cycloaddition under high pressure gave a good result, i.e., with practically quantitative conversion (Scheme 5). It was very important to reach such a conversion since it facilitated the separation of the pure product, which would have been difficult if the product had been a mixture of mono- and diisoxazoline. At room temperature the reaction between $p-(\mathrm{ONC})_{2} \mathrm{C}_{6} \mathrm{H}_{4}$ and $\mathbf{1 0}$ practically did not occur, whereas at $80{ }^{\circ} \mathrm{C}$ in a steel reactor (under equilibrium pressure) the yield of isoxazolines was $60 \%$, while $10 \%$ was the product of monoaddition. There is no doubt that considerable enhancement of yield is caused by high pressure activation. The reaction shown in Scheme 5 leading to 14 was the first 1,3-DC of nitrile oxide to alkenes under high pressure. In the literature, there are many examples reporting the beneficial, spectacular influence of high pressure on chemical reactions, cycloaddition reactions in particular, due to their highly negative activation volume [60-63]. There are many papers on diene-ene $[4+2]$ cycloadditions but the number of papers on dipolar $[3+2]$ cycloaddition is limited, furthermore, most of them concern the cycloaddition of nitrones to alkenes [62], and azides to alkynes $[61,63]$. There are no reports on the beneficial effects of high pressure on the 
cycloaddition reaction of nitrile oxide to alkenes. All five 1,3-DC reactions shown in Scheme 5 were concerted, since the trans/cis ratio for the isoxazolines obtained was the same as the $E / Z$ ratio for the dipolarophile (9/1). On the other hand, the regioselectivity of the cycloaddition presented in Scheme 5 was slightly different. In the case of dipolarophiles of $\mathrm{MeCH}=\mathrm{CHQ}$ type (as 10), the regioselectivity was very high or complete when Q was a strong donor, as it has been shown in our previous papers [46-48]. The content of the second regioisomer, i.e., 3-Ar, 4-bithienyl-5-methylisoxazolines depended on the type of $\mathrm{Ar}$ is $5 \%, 2 \%, 2 \% 1 \%$ and $1 \%$ for $2,6-\mathrm{Cl}_{2} \mathrm{C}_{6} \mathrm{H}_{3}, p-\mathrm{Me}_{2} \mathrm{NC}_{6} \mathrm{H}_{4}$, bt, $\mathrm{C}_{6} \mathrm{H}_{4}, 2-\mathrm{Py}$, respectively. It means that the reactions are highly regioselective, allowing one to obtain pure 5-bithienyl isoxazolines. In the case of the reaction with 2-pyridinecarbonitrile oxide, a side product, i.e., oxide dimer was isolated, which structure was confirmed by X-ray spectroscopy (Table S1 in Supporting Information). This dimer is a known compound [64], however, its X-ray structure is not known.

The obtained 5-(2,2'-bithiophen-5-yl)-3-(2,6-dichlorophenyl)-4-methylisoxazoline (11) and 5-(2,2'-bithiophen-5-yl)-3-( $p$-dimethylaminophenyl)-4-methylisoxazoline (12) were assumed as model compounds for 1,3-DC and aromatization. Compounds 1,4-bis(5-(2,2'-bithiophen-5-yl)-4methylisoxazoline-3-ylo)benzene (14) and 3,5-bis(2,2'-bithiophen-5-yl)-4-methylisoxazoline (15) are the precursors of conducting polymers of bt-A-bt type, where the spacer A contains an isoxazole ring. However, aromatization before polymerization is necessary. Isoxazoline 12 containing a 2-pyridylsubstituent is particularly interesting - it is a bidendate N,N-donor ligand and a precursor of a ligand which is an analogue of 2,2'-bipyridine (after aromatization). Both the dihydro form (isoxazoline) and, particularly, the fully aromatic form (isoxazole) may be used for the synthesis of molecular materials and conducting polymers. In the literature only a few transition metal (Pd, Pt, Re) complexes with 3-(2-pyridyl)isoxazolines, and also a few Ir and Re complexes with diisoxazoles [65] have been described. Importantly, such conducting polymers from the polythiophene group with isoxazole motif connecting the terthiophene fragments have not been reported. The obtained isoxazolines may be easily transformed into respective isoxazoles via oxidative dehydrogenation by DDQ, as it has been shown for two of them, i.e., 16, 17 (Scheme 6). The aromatization of isoxazolines shown in Scheme 6 was performed using a typical procedure [66].

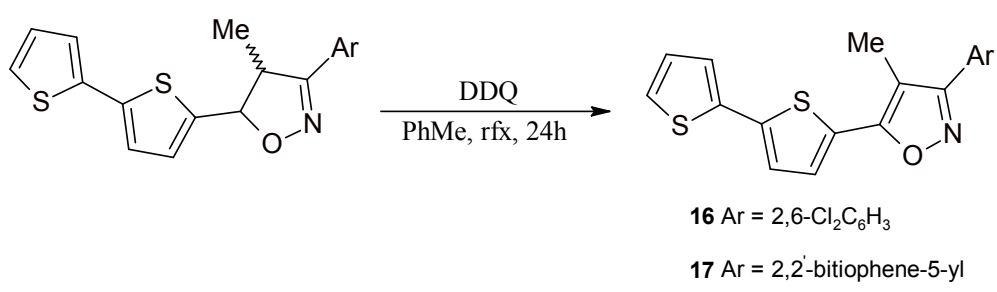

Scheme 6. Aromatization of isoxazolines using DDQ to: 3-(2,6-dichlorophenyl)-4-methyl-5(2,2'-bithiophen-5-yl)isoxazole (16) and 3,5-bis(2,2'-bithiophen-5-yl)-4-methylisoxazole (17).

The alternative route for the synthesis of isoxazoles via addition nitrile oxide to double bond and then aromatization can be the direct addition of RCNO into triple bond-see Scheme 7.

According to us, the reaction shown in Scheme 7 is a particularly spectacular example of the beneficial influence of high pressure on 1,3-DC. The conversion and the selectivity were practically quantitative, whereas under atmospheric or equilibrium pressure, in a steel reactor, this reaction does not take place even at $100{ }^{\circ} \mathrm{C}$ (in $\mathrm{CH}_{2} \mathrm{Cl}_{2}$ or DMF). 


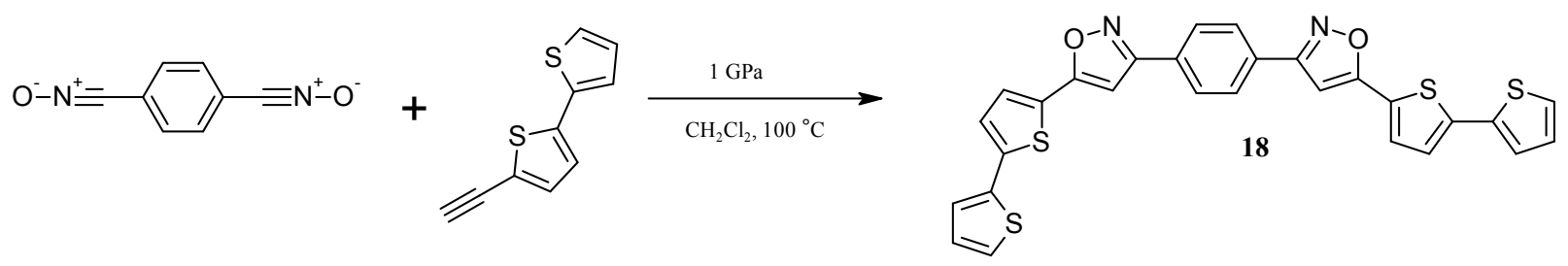

Scheme 7. Synthesis of 1,4-bis[5-(2,2'-bithiophen-5-yl)isoxazol-3-yl]benzene (18) via high pressure activated 1,3-DC cycloaddition of terephthaloyldinitrile to 5-ethynyl-2,2'-bithiophene.

\subsection{Rh-Mediated [2+2+2] Cycloaddition for Synthesis of Fluoranthene and Benzene Derivatives with a bt Motif}

Two new 7,8,9,10-tetrasubstituted fluoranthenes 19, $\mathbf{2 0}$ were obtained from 1,8-diethynylnaphthalene and 1,2-bis(2,2'-bithiophen-5-yl)ethyne (5) or 1,4-bis(2,2'-bithiophen-5-yl)1,3-butadiyne (6) derivatives via $\left[\mathrm{RhCl}\left(\mathrm{PPh}_{3}\right)_{3}\right]$-mediated formal $[2+2+2]$ cycloaddition (Scheme 8).

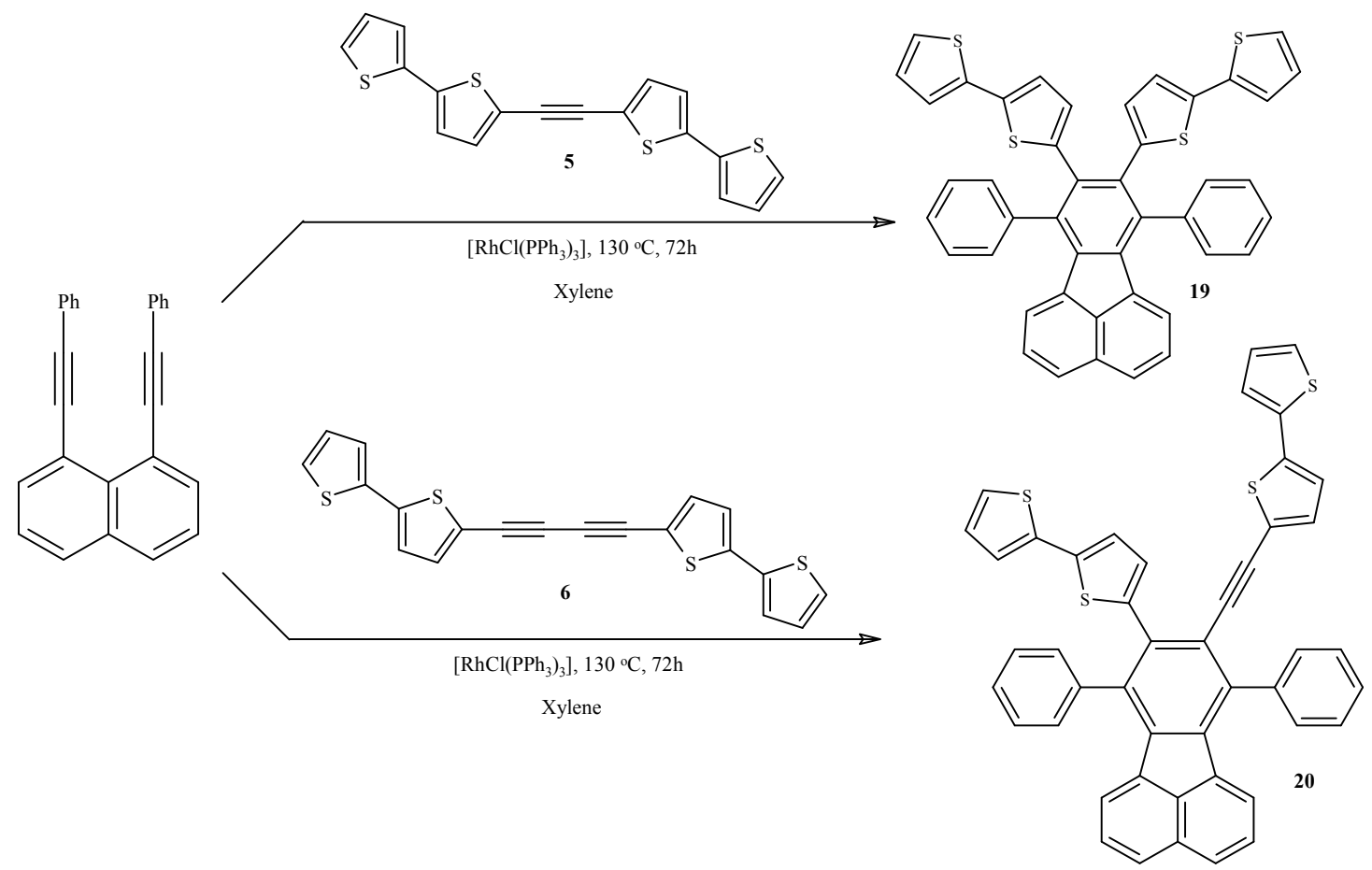

Scheme 8. Rh-mediated synthesis of fluoranthene derivatives containing 2,2'-bithiophen-5yl moiety: di(2,2'-bithienyl-5-yl)diphenylfluoranthene (19) and (2,2'-bithiophen-5-yl)[(2,2'bithiophen-5-yl)ethynyl]diphenylfluoranthene (20).

$\left[\mathrm{RhCl}\left(\mathrm{PPh}_{3}\right)_{3}\right]$ was applied as a catalyst since, together with $\left[\mathrm{Co}_{2}(\mathrm{CO})_{8}\right]$, it is the most frequently applied and effective catalyst for both inter- and intramolecular [2+2+2] cycloadditions [67-69]. In the literature there are only a few papers devoted to the synthesis of 7,8,9,10-tetrasubstituted fluoranthenes from derivatives of 1,8-diethynylnaphthalene and alkynes, except for conjugated diynes, or NBD which can act as an acetylene equivalent catalyzed by various rhodium complexes [67-69]. To date, fluoranthenes with alkyl or phenyl substituents, except for the ones with heteroaryl substituent, have been obtained in this way. Recently, several fluoranthenes with substituted thiophene motifs (except for the ones with a bithiophene one) and two fluoranthenes with a $6 H$-indolo[2,3-b]quinazoline 
chromophore [70] have been obtained. The compounds were obtained via [4 +2$]$, but not via $[2+2+2]$ cycloaddition. The novel compounds 19 and $\mathbf{2 0}$ are the first bithiophene derivatives of the bt-A-bt type, where the fluoroanthene fragment plays a role of a spacer. The polymers obtained from them are expected to have interesting conducting and luminescence properties.

The methods known from the literature were applied for the synthesis of diiodonaphthalene [71], was obtained from commercially available 1,8-diaminonaphthalene, which was further used to obtain a phenyl derivative via Sonogashira coupling [72]. The trimerization of the acetylene derivative 5, both in the reaction shown in Scheme 9 and during heating of 5 in xylene at $130{ }^{\circ} \mathrm{C}$ in the presence of $10 \mathrm{~mol} \%\left[\mathrm{RhCl}\left(\mathrm{PPh}_{3}\right)_{3}\right]$ was observed. The latter reaction allowed to obtain pure hexa(2,2'-bithiophen5-yl)benzene (21) with 40\% yield (Scheme 9). In the literature, there is only one work devoted to the trimerization of $\mathrm{ArC} \equiv \mathrm{CAr}$ ( $\mathrm{Ar}$ is alkyl-substituted- thienyl, bithienyl or terthienyl) to hexakis(alkylthienyl-, bithienyl and terthienyl)benzenes catalyzed by $\left[\mathrm{Co}_{2}(\mathrm{CO})_{8}\right]$ [73].

Our result, i.e., the trimerization of $\mathbf{5}$, corresponds to the results of other authors, who used $\left[\mathrm{RhCl}\left(\mathrm{PPh}_{3}\right)_{3}\right]$ with very good results for fully intermolecular [2+2+2] cycloaddition [67]. However, trimerization of 1,4-bis(2,2'-bithiophen-5-yl)-1,3-butadiyne was not observed despite the fact that such a reaction is known for 1,4-diphenyl-1,3-butadiyne [67]. It probably results from the steric effects being greater for the 2,2-bitihophen-5-yl substituent than for the phenyl one, which have a major influence on the course of the studied cycloaddition reactions. One should remember that this reaction probably proceeds via a metalacyclopentadiene intermediate and steric hindrance plays a crucial role in this transformation [67]. Moreover, in accordance with the results of $\mathrm{Wu}$ et al., the thermal, intramolecular transformation of 1,8-di(phenylethyl)naphthalene to 7-phenylbenzo[k]fluoranthene described by Bossenbroek et al., was not observed by us [74].

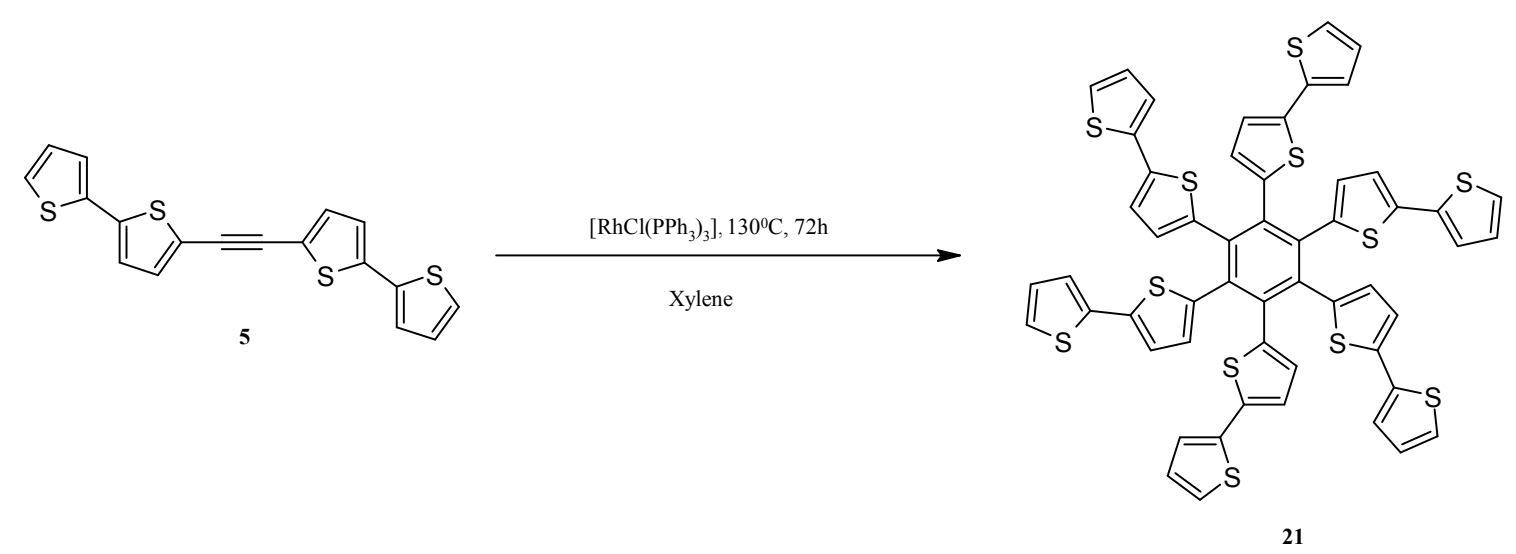

Scheme 9. Cyclotrimerization of 1,2-bis(2,2'-bithiophen-5-yl)acetylene (5) to hexa(2,2'bithiophen-5-yl)benzene (21) catalyzed by $\left[\mathrm{RhCl}\left(\mathrm{PPh}_{3}\right)_{3}\right]$.

\subsection{Catalytically or High Pressure Activated 1,3-DC of Azides to Triple Bond for Synthesis of} Triazoles with bt Moiety

Using 5-iodobithiophene (3), 5-ethynylbithiophene (4), 1,2-bis(2,2'-bithiophen-5-yl)acetylene (5) and $\mathrm{Cu}$-catalyst or $\mathrm{Ru}$-catalyst or high pressure mediated 1,3-dipolar cycloaddition of azides to alkynes, four novel triazole derivatives 22-25 containing one or two bt moieties were obtained (Scheme 10). In these syntheses, typical catalytic systems, i.e., $\mathrm{CuSO}_{4} /$ sodium ascorbate [75-77] or 
[RuClcp $\left.\left(\mathrm{PPh}_{3}\right)_{2}\right][78,79]$ or high pressure activation were used. The use of high pressure in the 1,3-DC of azides to alkynes has already been described [63,80], although not for heteroaryl-substituted alkynes. Decyl, benzyl, and bithienyl azides [13] were synthesized using the methods known from the literature (the latter was generated in situ).
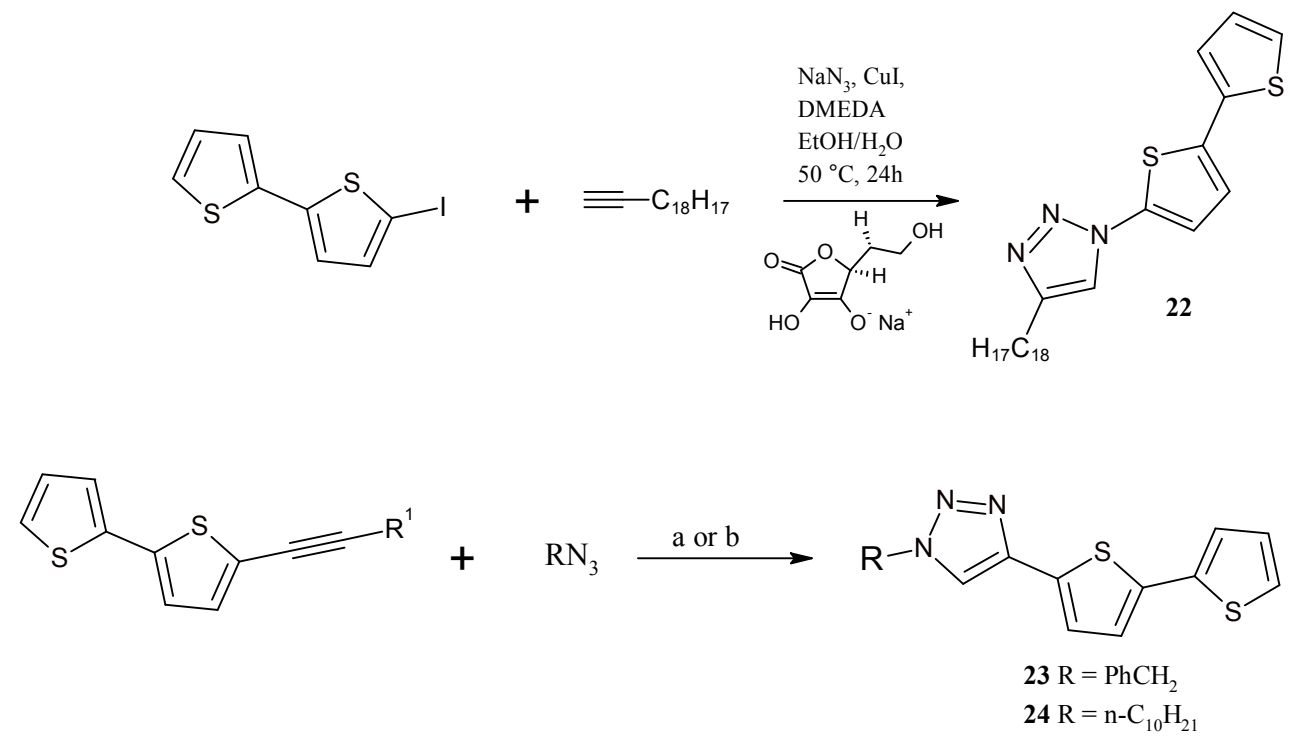

a) sodium ascorbate, $\mathrm{CuSO}_{4} * 5 \mathrm{H}_{2} \mathrm{O}, \mathrm{K}_{2} \mathrm{CO}_{3}$, t- $\mathrm{BuOH} / \mathrm{H}_{2} \mathrm{O}$, rt, $48 \mathrm{~h}$ when $\mathrm{R}^{1}=\mathrm{SiMe}_{3}$ and $\mathrm{R}^{2}=\mathrm{PhCH}_{2}$;

b) $1.0 \mathrm{GPa}, 80{ }^{\circ} \mathrm{C}, 24 \mathrm{~h}$ when $\mathrm{R}^{1}=\mathrm{H}$ and $\mathrm{R}^{2}=\mathrm{n}-\mathrm{C}_{10} \mathrm{H}_{21}$;

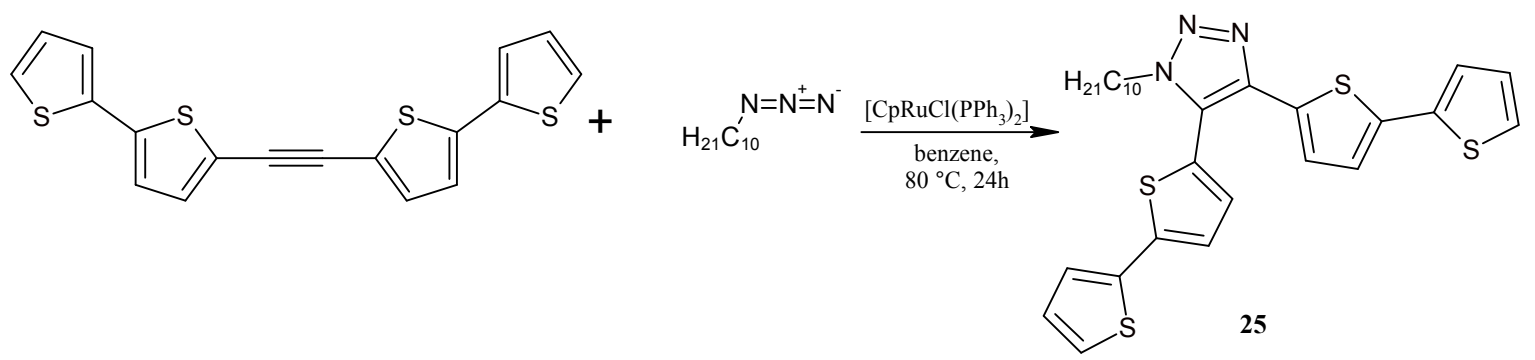

Scheme 10. Cu- or Ru-catalyst or hp-mediated synthesis of triazoles 22-25 with a bt moiety.

It should be noted that the reaction carried out under high pressure is fully regioselective - only 4-(2,2'-bithiophen-5-yl)triazole is formed. The obtained triazoles may play the role as cyclometalating ligands or monomers for the synthesis of polythiophenes, where the triazole ring is the linker connecting tetrathiophene fragments. Up till now, this type of conducting polythiophenes has not been known. Moreover, there are a lot of triazoles which play a vital role of ligands in the molecular catalysis described in the literature [75]. Additionally, a triazole motif is present in the structure of many pharmaceuticals, in particular antifungal ones [81].

\subsection{Synthesis of Pyrroles with two bt Moieties via CuCl-Mediated Dihydroamination of 1,4-Bis(2,2'-} bithiophene-5-yl)buta-1,3-diyne

Three new pyrrole derivatives 26-28 were also obtained via CuCl-mediated hydroamination of 1,4-bis(2,2'-bithiophen-5-yl)buta-1,3-diyne (6) (Scheme 11). The addition of $\mathrm{RNH}_{2}$ to 1,3-diynes 
(hydroamination of 1,3-diynes) catalyzed with transition metal complexes leading to pyrrole derivatives is an alternative to classical Knorr, Paal-Knorr, and Hantzsch methods. The effective catalysts of these reactions are complexes of $\mathrm{Au}(\mathrm{I})$ [82,83], $\mathrm{Au}(\mathrm{I})-\mathrm{H}_{3} \mathrm{PO}_{4}-12 \mathrm{WO}_{3}$ [84], and $\mathrm{CuCl}$ [85-87] - the yields of these reactions range from moderate to very high. Convenient procedures for many disubstituted diynes, even for 1,4-bis(2-thienyl)-1,3-butadiyne are known [85-88]. Moreover, several aromatic and aliphatic amines were used for the abovementioned procedures [85-88].

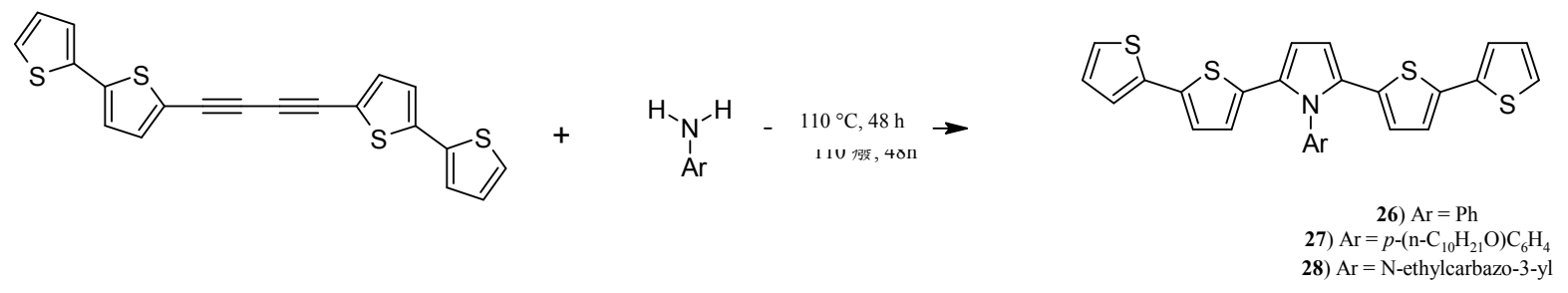

Scheme 11. Synthesis of: $N$-phenyl-2,5-bis(2,2'-bithiophen-5-yl)pyrrole (26); $N$-(pdecyloxyphenyl)-2,5-bis(2,2'-bithiophen-5-yl)pyrrole (27) and $N$-[2-(N-carbazo-3yl)ethyl]-2,5-bis(2,2'-bithiophen-5-yl)pyrrole (28) via CuCl-catalyzed dihydroamination of 1,4-bis(2,2'-bithiophen-5-yl)-1,3-butadiyne (6).

It was shown that it is possible to obtain pyrroles with 2,2'-bithiophen-5-yl substituents in positions 2 and 5, and most of all, that aminoheteroarenes may also serve as substrates in this synthesis. Importantly, the synthesis yield of the derivative substituted with $N$-ethylcarbazo-3-yl was much higher than for phenyl and $p$-decyloxyphenyl substituents. The synthesized compounds $\mathbf{2 6 - 2 8}$ will be certainly very interesting as nanomaterials due to the $\pi$-excessive character of the pyrrole and bithiophene fragments, luminescence, and solubility in organic solvents. There are only two similar systems known in the literature [89]. Nevertheless, these systems contain a thiophene (not bithiophene) motif, i.e., 3,6-bis(2,5-di-2-thienyl-1H-pyrrol-1-yl)-9-ethyl(or dodecyl)-9H-carbazole, which were classically obtained from 1,4-bis(2-thienyl)buta-1,4-dione [89]. The mechanism of dihydroamination of conjugated diynes catalysed by $\mathrm{CuCl}$ has not been described in detail so far. Nevertheless, it is probably similar to the well-known addition of amines to disubstituted acetylenes catalyzed by various transition metal complexes [90].

\section{Experimental Section}

\subsection{General Methods}

All starting materials and reagents were purchased from commercial sources and were used as received, unless otherwise stated. All reactions were carried out under argon atmospheres undernhydrous conditions. Solvents were dried and purified using usual methods before use. Thin layer chromatography was performed on silica gel (TLC silica gel 60, Merck, Darmstadt, Germany). NMR spectra were recorded on an Avance 400 instrument $\left(400 \mathrm{MHz}\right.$ for ${ }^{1} \mathrm{H}$ and $100 \mathrm{MHz}$ for ${ }^{13} \mathrm{C}$ ) or Ascend 500 instrument (500 MHz for ${ }^{1} \mathrm{H}$ and $125 \mathrm{MHz}$ for ${ }^{13} \mathrm{C}$ ) (Bruker, Billerica, MA, USA). Chemical shifts were referenced to the residual proton signal of the solvent. Melting point measurements were conducted on Stuart automatic melting point SMP40 apparatus (Bibby Scientific 
Limited Group, Staffordshire, United Kingdom). Low resolution mass spectra were recorded in methanol on a Varian LC-920 instrument (Varian, Palo Alto, CA, USA). HRMS-ESI spectra were recorded in methanol on a Synapt G2-S HDMS mass spectrometer (Waters Inc., Milford, MA, USA) equipped with an electrospray ion source and q-TOF type mass analyzer. HRMS-EI spectra were recorded on an AutoSpec Premier magnetic sector mass spectrometer (Waters Inc.) equipped with an electron impact (EI) ion source and the EBE double focusing geometry mass analyzer. The setup for reactions under high pressure conditions was built for high pressure dielectric measurements by UNIPRESS (Warsaw, Poland) and described by Paluch et al. [91].

The crystals of compounds were mounted in turn on a Gemini Ultra Oxford Diffraction automatic diffractometer (Agilent, Santa Clara, CA, USA) equipped with a CCD detector, and used for data collection. X-ray intensity data was collected with graphite monochromated $\mathrm{Mo} K_{\alpha}$ radiation $(\lambda=0.71073 \AA)$ at a temperature of $295.0(2) \mathrm{K}$, with $\omega$ scan mode. Ewald sphere reflections were collected up to $2 \theta 50.10$. Details concerning crystal data and refinement is gathered in Tables S1-S3. Lorentz, polarization and empirical absorption corrections using spherical harmonics implemented in SCALE3 ABSPACK scaling algorithm [92]. The structures were solved by the direct method and subsequently completed by difference Fourier recycling. All the non-hydrogen atoms were refined anisotropically using full-matrix, least-squares techniques. The Olex2 [93] and SHELXS97, SHELXL97 [94] programs were used for all the calculations. Atomic scattering factors were incorporated in the computer programs.

\subsection{Synthesis of 1,2-Bis(2,2'-bithiophene-5-yl)acetylene (5) and 1,4-Bis(2,2'-bithiophene-5-yl)buta-} 1,3-diyne (6)

A cascade of three reactors, each containing a mixture of substrates consisting of 5-iodo-2,2'bithiophene (15.0 g, $51.3 \mathrm{mmol})$, $\mathrm{CuI}(1.125 \mathrm{~g}, 5.9 \mathrm{mmol})$, [ $\left.\mathrm{PdCl}_{2}\left(\mathrm{PPh}_{3}\right)_{2}\right](0.75 \mathrm{~g}, 1.1 \mathrm{mmol})$, acetone $(500 \mathrm{~mL})$, triethylamine $(11.25 \mathrm{~mL}, 81 \mathrm{mmol})$, was saturated with a steady stream of acetylene (for 5) or buta-1,3-diyne (generated from 1,4-dichloro-2-butyne (12.64 g, $0.1 \mathrm{~mol}$ ), according to the procedure described in literature [95] in temperature range from 70 to $75{ }^{\circ} \mathrm{C}$ for $30 \mathrm{~min}, 1 \mathrm{~mol} / 6 \mathrm{~h}$ for 6), mixed with argon $(1: 10 \mathrm{v} / \mathrm{v})$ at room temperature for $6 \mathrm{~h}$. After the flow of gas was finished, the content of the reactors was left to stir for $24 \mathrm{~h}$ at room temperature. Then the volatile fractions from the combined mixtures were evaporated on a rotary evaporator. Crude product was purified using column chromatography ( $\mathrm{SiO}_{2}$, hexane). A yellow solid was obtained in $60 \%$ and $75 \%$ yield for $\mathbf{5}$ and 6, respectively.

Compound 5:

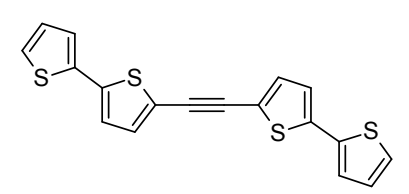

${ }^{1} \mathrm{H}-\mathrm{NMR}\left(\mathrm{CDCl}_{3}\right): \delta 7.25(\mathrm{dd}, J=5.1 \mathrm{~Hz}, \mathrm{~J}=3.6 \mathrm{~Hz}, 2 \mathrm{H}), 7.20(\mathrm{dd}, J=3.6 \mathrm{~Hz}, J=1.1 \mathrm{~Hz}, 2 \mathrm{H}), 7.18$ $(\mathrm{d}, J=3.8 \mathrm{~Hz}, 2 \mathrm{H}), 7.07(\mathrm{~d}, J=3.8 \mathrm{~Hz}, 2 \mathrm{H}), 7.03(\mathrm{dd}, J=5.1 \mathrm{~Hz}, J=3.6 \mathrm{~Hz}, 2 \mathrm{H}) .{ }^{13} \mathrm{C}-\mathrm{NMR}\left(\mathrm{CDCl}_{3}\right)$ : $\delta 139.53,136.79,133.15,128.12,125.17,124.50,123.77,121.55,87.43$. HRMS (EI) calcd. for $\mathrm{C}_{18} \mathrm{H}_{10} \mathrm{~S}_{2} 353.96654$ found 353.93537. 
Compound 6:

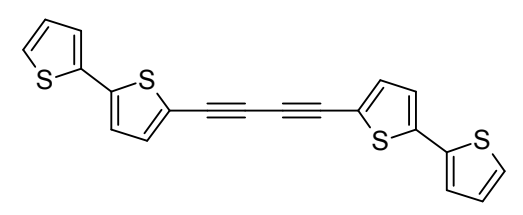

${ }^{1} \mathrm{H}-\mathrm{NMR}\left(\mathrm{CDCl}_{3}\right): \delta 7.26(\mathrm{dd}, J=5.1 \mathrm{~Hz}, J=1.1 \mathrm{~Hz}, 2 \mathrm{H}), 7.25(\mathrm{~d}, J=3.8 \mathrm{~Hz}, 2 \mathrm{H}), 7.21(\mathrm{dd}, J=3.6 \mathrm{~Hz}$, $J=1.1 \mathrm{~Hz}, 2 \mathrm{H}), 7.05(\mathrm{~d}, J=3.8 \mathrm{~Hz}, 2 \mathrm{H}), 7.03(\mathrm{dd}, J=5.1 \mathrm{~Hz}, J=3.6 \mathrm{~Hz}, 2 \mathrm{H}) .{ }^{13} \mathrm{C}-\mathrm{NMR}(100 \mathrm{MHz}$, $\left.\mathrm{CDCl}_{3}\right): \delta 140.82,136.56,135.52,128.19,125.69,124.92,123.74,120.66,79.16,77.59$. HRMS (EI) calcd for $\mathrm{C}_{20} \mathrm{H}_{10} \mathrm{~S}_{4}[\mathrm{M}]^{+} 377.9665$ found 377.9669 .

3.3. Synthesis of 1,4-Bis(2,2'-bithiophene-5-yl)-3-methyl-2-ethoxycarbonylbenzene (7) and 1,4Bis(2,2'-bithiophene-5-yl)-3-phenyl-2-ethoxycarbonylbenzene (8)

The mixture of ethyl acetoacetate (for synthesis of 7) or ethylbenzoyl acetate (for synthesis of 8 ) (1.28 mmol) with 5-ethynyl-2,2'-bithiophene (609 mg, $3.20 \mathrm{mmol}),[\mathrm{MnBr}(\mathrm{CO}) 5]$ (20 mg, $0.0735 \mathrm{mmol})$, and powdered $4 \AA$ molecular sieves (23 mg; $115 \mathrm{wt} \%$-Mn cat.) was vigorously stirred and heated at $80{ }^{\circ} \mathrm{C}$ for $48 \mathrm{~h}$. Crude product was purified using column chromatography ( $\mathrm{SiO}_{2}$, toluene-petroleum ether 3:1). Compounds 7 and $\mathbf{8}$ were isolated in $60 \%$ and $70 \%$ yield, respectively, as yellow solids.

1,4-Bis(2,2'-bithiophene-5-yl)-3-methyl-2-etoxycarbonylbenzene (7). ${ }^{1} \mathrm{H}-\mathrm{NMR}$ (400 $\left.\mathrm{MHz}, \mathrm{CDCl}_{3}\right): \delta$ $7.48(\mathrm{~d}, J=8.0 \mathrm{~Hz}, 1 \mathrm{H}), 7.38(\mathrm{~d}, J=8.0 \mathrm{~Hz}, 1 \mathrm{H}), 7.25-7.23(\mathrm{~m}, 2 \mathrm{H}), 7.21(\mathrm{dd}, J=3.4 \mathrm{~Hz}, J=1.0 \mathrm{~Hz}$, $1 \mathrm{H}), 7.20(\mathrm{dd}, J=3.4 \mathrm{~Hz}, J=1.0 \mathrm{~Hz}, 1 \mathrm{H}), 7.17(\mathrm{~d}, J=3.7 \mathrm{~Hz}, 1 \mathrm{H}), 7.13(\mathrm{~d}, J=3.7 \mathrm{~Hz}, 1 \mathrm{H})$, $7.06-7.02(\mathrm{~m}, 3 \mathrm{H}), 6.97(\mathrm{~d}, J=3.7 \mathrm{~Hz}, 1 \mathrm{H}), 4.30$ (q, $J=7.1 \mathrm{~Hz}, 2 \mathrm{H}), 2.45(\mathrm{~s}, 1 \mathrm{H}), 1.24(\mathrm{t}, J=7.1 \mathrm{~Hz}$, $3 \mathrm{H}) .{ }^{13} \mathrm{C}-\mathrm{NMR}\left(125 \mathrm{MHz}, \mathrm{CDCl}_{3}\right): \delta 169.68,140.63,140.12,138.22,137.94,137.10,137.08,134.74$, $134.27,133.44,131.44,131.18,128.03,127.90,127.37,127.07,124.62,124.59,124.15,123.88$, 123.84, 61.62, 18.05, 13.96. HRMS (EI) calcd for $\mathrm{C}_{26} \mathrm{H}_{20} \mathrm{O}_{2} \mathrm{~S}_{4}[\mathrm{M}]^{+} 492.0346$ found 492.0361 .

1,4-Bis(2,2'-bithiophene-5-yl)-3-phenyl-2-etoxycarbonylbenzene (8). ${ }^{1} \mathrm{H}-\mathrm{NMR}\left(400 \mathrm{MHz}, \mathrm{CDCl}_{3}\right): \delta$ $7.67(\mathrm{~d}, J=8.2 \mathrm{~Hz}, 1 \mathrm{H}), 7.55(\mathrm{~d}, J=8.2 \mathrm{~Hz}, 1 \mathrm{H}), 7.36-7.27(\mathrm{~m}, 5 \mathrm{H}), 7.23(\mathrm{dd}, J=5.0 \mathrm{~Hz}, J=0.7 \mathrm{~Hz}$, $1 \mathrm{H}), 7.20(\mathrm{dd}, J=3.6 \mathrm{~Hz}, J=0.8 \mathrm{~Hz}, 1 \mathrm{H}), 7.17(\mathrm{dd}, J=5.1 \mathrm{~Hz}, J=0.9 \mathrm{~Hz}, 1 \mathrm{H}), 7.12(\mathrm{~d}, J=3.7 \mathrm{~Hz}, 1 \mathrm{H})$, $7.09(\mathrm{~d}, J=3.8 \mathrm{~Hz}, 1 \mathrm{H}), 7.05(\mathrm{dd}, J=3.5 \mathrm{~Hz}, J=0.8 \mathrm{~Hz}, 1 \mathrm{H}), 7.03(\mathrm{dd}, J=5.0 \mathrm{~Hz}, J=3.6 \mathrm{~Hz}, 1 \mathrm{H})$, $6.97(\mathrm{dd}, J=5.0 \mathrm{~Hz}, J=3.6 \mathrm{~Hz}, 1 \mathrm{H}), 6.89(\mathrm{~d}, J=3.8 \mathrm{~Hz}, 1 \mathrm{H}), 6.50(\mathrm{~d}, J=3.8 \mathrm{~Hz}, 1 \mathrm{H}), 3.90$ (q, $J=7.1 \mathrm{~Hz}, 2 \mathrm{H}), 0.89$ (t, $J=7.1 \mathrm{~Hz}, 3 \mathrm{H}) .{ }^{13} \mathrm{C}-\mathrm{NMR}\left(125 \mathrm{MHz}, \mathrm{CDCl}_{3}\right): \delta 168.55,140.72,139.72$, $138.31,138.02,138.00,137.87,137.16,137.11,134.85,133.25,130.49,130.30,130.26,129.14$, 128.09, 128.00, 127.89, 127.79, 127.31, 124.64, 124.41, 124.30, 123.90, 123.69, 123.61, 61.23, 13.56 . HRMS (EI) calcd for $\mathrm{C}_{31} \mathrm{H}_{22} \mathrm{O}_{2} \mathrm{~S}_{4}[\mathrm{M}]^{+} 554.0503$ found 554.0482 .

\subsection{Synthesis of 5-Allyl-2,2'-bithiophene (9)}

1.6 $\mathrm{M}$ solution of $n$-BuLi in hexane $(60.2 \mathrm{~mL}, 96.2 \mathrm{mmol})$ was injected through septum with a syringe (for about $30 \mathrm{~min}$.) to vigorously stirred solution of 2,2'-bithiophene (1, $20 \mathrm{~g}, 120.3 \mathrm{mmol}$ ) in the mixture of hexane $(1 \mathrm{~L})$ and diethyl ether $(350 \mathrm{~mL})$ cooled down to below $-5^{\circ} \mathrm{C}$. It was necessary to keep the temperature of reaction mixture below $-5^{\circ} \mathrm{C}$ during the injection of $n$-BuLi solution. After all $\mathrm{n}$-BuLi was added, the cooling bath was removed and reaction mixture was left to reach room 
temperature. In the next step, allyl bromide $(14.5 \mathrm{~g}, 120.3 \mathrm{mmol})$ was added dropwise through septum with a syringe. The reaction mixture was stirred for $72 \mathrm{~h}$ at room temperature and the progress of the reaction was monitored with TLC. After that, the post-reaction mixture was filtered and the solvents were evaporated from the filtrate using a rotary evaporator. The crude product was purified using column chromatography ( $\mathrm{SiO}_{2}$, hexane). Product 9 was obtained as yellowish liquid in $85 \%$ yield.

Isomerization of 5-Allyl-2,2'-bithiophene (9), N-allylimidazole and Allyl-phenyl sulfide to 1-propenyl derivatives catalysed by $15-$ crown- $5 / \mathrm{NaOH}$

Allyl substrate $(10 \mathrm{mmol}), 15$-crown-5 $(10 \mathrm{mmol})$, micronized $\mathrm{NaOH}(10 \mathrm{mmol})$ and toluene $(1 \mathrm{~mL})$ were vigorously stirred at room temperature for $24 \mathrm{~h}$. After that, toluene $(10 \mathrm{~mL})$ was added and the mixture was washed with water (3 times $10 \mathrm{~mL}$ ) and dried over anhydrous $\mathrm{MgSO}_{4}$. After drying an agent was filtered out, activated carbon $(20 \mathrm{mg})$ was added and the mixture was stirred for $3 \mathrm{~h}$ at room temperature. After that, activated carbon was filtered out and the solvent was evaporated on a rotary evaporator. Pure $(E+Z)$-(1-propenyl) derivatives were obtained with 97\% yield.

\subsection{Synthesis of $(E)+(Z)-5-(1-P r o p e n y l)-2,2$ '-bithiophene (10)}

A mixture of 5-allyl-2,2'-bithiophene (9) (2 g, $10 \mathrm{mmol}),\left[\mathrm{RuClH}(\mathrm{CO})\left(\mathrm{PPh}_{3}\right)_{3}\right](10 \mathrm{mg}, 0.1 \mathrm{mmol})$ and toluene $(1 \mathrm{~mL})$ was stirred at $60{ }^{\circ} \mathrm{C}$ for $24 \mathrm{~h}$. The solvent was evaporated using a rotary evaporator and the solid residue was purified using column chromatography ( $\mathrm{SiO}_{2}$, hexane). Ru-free $\mathbf{1 0}$ was obtained with $97 \%$ yield $(\mathrm{E} / \mathrm{Z}=9)$ as a light-brown oil.

Compound (10):

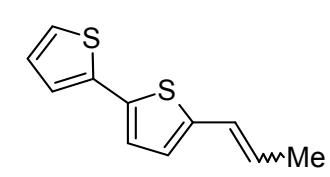

${ }^{1} \mathrm{H}-\mathrm{NMR}\left(400 \mathrm{MHz}, \mathrm{C}_{6} \mathrm{D}_{6}\right): \delta 1.54(\mathrm{dd}, J=6.7 \mathrm{~Hz}, J=1.7 \mathrm{~Hz}, 3 \mathrm{H}), 1.81(\mathrm{dd}, J=7.3 \mathrm{~Hz}, J=1.7 \mathrm{~Hz}$, $3 \mathrm{H}), 5.47$ (dq, $J=11.4 \mathrm{~Hz}, J=7.3 \mathrm{~Hz}, 1 \mathrm{H}), 5.89(\mathrm{dq}, J=15.5 \mathrm{~Hz}, J=6.7 \mathrm{~Hz}, 1 \mathrm{H}), 6.23$ (dtd, $J=15.5 \mathrm{~Hz}, J=1.6 \mathrm{~Hz}, J=1,1 \mathrm{~Hz}, 1 \mathrm{H}), 6.39(\mathrm{ddd}, J=11.4 \mathrm{~Hz}, J=1.7 \mathrm{~Hz}, J=0.5 \mathrm{~Hz}, 1 \mathrm{H}), 6.50$ $(\mathrm{d}, J=3,7 \mathrm{~Hz}, 1 \mathrm{H}), 6.52(\mathrm{~d}, J=3,7 \mathrm{~Hz}, 1 \mathrm{H}), 6.64(\mathrm{dd}, J=5.1 \mathrm{~Hz}, J=3.6 \mathrm{~Hz}, 1 \mathrm{H}), 6.65(\mathrm{dd}, J=5.1 \mathrm{~Hz}$, $J=3.6 \mathrm{~Hz}, 1 \mathrm{H}), 6.71(\mathrm{dd}, J=5.1 \mathrm{~Hz}, J=1.1 \mathrm{~Hz}, 2 \mathrm{H}), 6.88(\mathrm{~d}, J=3.7 \mathrm{~Hz}, 1 \mathrm{H}), 6.93(\mathrm{~d}, J=3.7 \mathrm{~Hz}$, $1 \mathrm{H}), 6.08(\mathrm{dd}, J=3.6 \mathrm{~Hz}, J=1.2 \mathrm{~Hz}, 1 \mathrm{H}), 7.00(\mathrm{dd}, J=3.6 \mathrm{~Hz}, J=1.2 \mathrm{~Hz}, 1 \mathrm{H}) .{ }^{13} \mathrm{C}-\mathrm{NMR}$ $\left(100 \mathrm{MHz} \mathrm{CDCl}_{3}\right): \delta 142.26,137.84,137.53,134.93,127.93,127.92,127.92,126.10,126.10,125.08$, $125.08,124.47,124.46,124.46,124.20,123.92$, 123.92, 123.88, 123.88, 123.50, 18.52, 15.39. HRMS (EI) calcd for $\mathrm{C}_{11} \mathrm{H}_{10} \mathrm{~S}_{2}[\mathrm{M}]^{+} 206.02239$ found 206.02162 .

\subsection{General Procedure for 1,3-Dipolar Cycloaddition: Synthesis of 11-13}

To a solution of aldoxime (1.29 mmol) and NCS (1.50 mmol) in $\mathrm{CH}_{2} \mathrm{Cl}_{2}$ (or DMF for 13 ) (12 mL), one drop of $36 \%$ hydrochloric acid was added. The reaction mixture was stirred at room temperature for $24 \mathrm{~h}$. After that time, $(E+Z)$-5-(1-propenyl)-2,2'-bithiophene (10) (266 mg, $1.29 \mathrm{mmol})$ and triethylamine $(0.10 \mathrm{~mL}, 1.41 \mathrm{mmol})$ were added and the reaction mixture was stirred at $40{ }^{\circ} \mathrm{C}$ for $24 \mathrm{~h}$. In the next step, solvent was removed using a rotary evaporator. The crude product was purified using 
column chromatography ( $\mathrm{SiO}_{2}, \mathrm{CH}_{2} \mathrm{Cl}_{2}$ ). Products 11 (61\% yield, yellow solid), 12 (29\% yield, pale-red oil), and 13 (34\% yield, pale-brown oil) were isolated. During isolation of the isoxazoline 13 the dimer of 2-pyridinecarbonitrile oxide 13a was additionally obtained (5\% yield, pale yellow crystals).

5-(2,2'-Bithiophen-5-yl)-3-(2,6-dichlorophenyl)-4-methylisoxazoline (11). ${ }^{1} \mathrm{H}-\mathrm{NMR} \quad(400 \mathrm{MHz}$, $\left.\mathrm{CDCl}_{3}\right): \delta 7.44-7.31(\mathrm{~m}, 3 \mathrm{H}), 7.26(\mathrm{~d}, J=5.1 \mathrm{~Hz}, 1 \mathrm{H}), 7.21(\mathrm{~d}, J=3.6 \mathrm{~Hz}, 1 \mathrm{H}), 7.10(\mathrm{~s}, 2 \mathrm{H}), 7.05(\mathrm{dd}$, $J=4.6 \mathrm{~Hz}, J=3.6 \mathrm{~Hz}, 1 \mathrm{H}), 6.08(\mathrm{~d}, J=10.3 \mathrm{~Hz}, 1 \mathrm{H}), 5.50(\mathrm{~d}, J=10.0 \mathrm{~Hz}, 1 \mathrm{H}), 4.98(\mathrm{dq}, J=9.3 \mathrm{~Hz}$, $J=6.1 \mathrm{~Hz}, 1 \mathrm{H}), 4.87(\mathrm{~d}, J=9.4 \mathrm{~Hz}, 1 \mathrm{H}), 4.09-4.01(\mathrm{~m}, 1 \mathrm{H}), 3.97(\mathrm{dq}, J=10.0 \mathrm{~Hz}, J=7.1 \mathrm{~Hz}, 1 \mathrm{H}), 1.65$ $(\mathrm{d}, J=6.1 \mathrm{~Hz}, 1 \mathrm{H}), 1.31$ (d, $J=7.1 \mathrm{~Hz}, 3 \mathrm{H}), 1.00$ (d, $J=7.5 \mathrm{~Hz}, 1 \mathrm{H}) .{ }^{13} \mathrm{C}-\mathrm{NMR}\left(100 \mathrm{MHz}, \mathrm{CDCl}_{3}\right): \delta$ $160.88,139.80,136.38,135.98,131.32,128.17,128.10,127.95,127.72,127.38,125.46,124.63$, 124.23, 109.70, 77.35, 77.04, 76.72, 8.09. m.p. $149 \pm 1.2^{\circ} \mathrm{C}$. HRMS (EI) calcd for $\mathrm{C}_{18} \mathrm{H}_{13} \mathrm{Cl}_{2} \mathrm{NOS}_{2}$ $[\mathrm{M}]^{+}: 392.98156$ found 392.98123 .

4-[5-(2,2'-Bithiophen-5-yl)-4-methyl-4,5-dihydroisoxazol-3-yl]-N,N-dimethylaniline (12). cis ${ }^{1} \mathrm{H}-\mathrm{NMR}$ (400 MHz, $\left.\mathrm{CDCl}_{3}\right): \delta 1.43(\mathrm{~d}, J=7.1 \mathrm{~Hz}, 3 \mathrm{H}), 2.88(\mathrm{~s}, 6 \mathrm{H}), 3.77(\mathrm{qd}, J=7.1 \mathrm{~Hz}, J=4.8 \mathrm{~Hz}, 1 \mathrm{H})$, $5.45(\mathrm{dd}, J=4.8 \mathrm{~Hz}, J=0.5 \mathrm{~Hz}, 1 \mathrm{H}), 6.69(\mathrm{dd}, J=8.4 \mathrm{~Hz}, J=2.1 \mathrm{~Hz}, 1 \mathrm{H}), 6.96(\mathrm{dd}, J=3.7 \mathrm{~Hz}$, $J=0.6 \mathrm{~Hz}, 1 \mathrm{H}), 6.99(\mathrm{dd}, J=5.1 \mathrm{~Hz}, J=3.6 \mathrm{~Hz}, 1 \mathrm{H}), 7.02(\mathrm{~d}, J=3.6 \mathrm{~Hz}, 1 \mathrm{H}), 7.12(\mathrm{dd}, J=3.6 \mathrm{~Hz}$, $J=1.1 \mathrm{~Hz}, 1 \mathrm{H}), 7.20(\mathrm{dd}, J=5.1 \mathrm{~Hz}, J=1.1 \mathrm{~Hz}, 1 \mathrm{H}), 7.55(\mathrm{dd}, J=8.4 \mathrm{~Hz}, J=2.1 \mathrm{~Hz}, 1 \mathrm{H}), 7.72(\mathrm{~d}$, $J=2.1 \mathrm{~Hz}, 1 \mathrm{H}) . \operatorname{trans}{ }^{1} \mathrm{H}-\mathrm{NMR}\left(400 \mathrm{MHz}, \mathrm{CDCl}_{3}\right): \delta 1.44(\mathrm{~d}, J=7.1 \mathrm{~Hz}, 3 \mathrm{H}), 3.00(\mathrm{~s}, 6 \mathrm{H}), 3.78$ (dq, $J=7.1 \mathrm{~Hz}, J=4.4 \mathrm{~Hz}, 1 \mathrm{H}), 5.41(\mathrm{dd}, J=4.4 \mathrm{~Hz}, J=0.5 \mathrm{~Hz}, 1 \mathrm{H}), 6.70-6.73(\mathrm{~m}, 2 \mathrm{H}), 6.96(\mathrm{dd}$, $J=3.7 \mathrm{~Hz}, J=0.6 \mathrm{~Hz}, 1 \mathrm{H}), 6.98(\mathrm{dd}, J=5.1 \mathrm{~Hz}, J=3.6 \mathrm{~Hz}, 1 \mathrm{H}), 7.01(\mathrm{~d}, J=3.6 \mathrm{~Hz}, 1 \mathrm{H}), 7.11(\mathrm{dd}$, $J=3.6 \mathrm{~Hz}, J=1.1 \mathrm{~Hz}, 1 \mathrm{H}), 7.18(\mathrm{dd}, J=5.1 \mathrm{~Hz}, J=1.1 \mathrm{~Hz}, 1 \mathrm{H}), 7.58-7.62(\mathrm{~m}, 2 \mathrm{H})$. cis ${ }^{13} \mathrm{C}-\mathrm{NMR}$ $\left(100 \mathrm{MHz}, \mathrm{CDCl}_{3}\right): \delta 17.76,43.45,50.51,85.76,115.78,122.88,123.33,124.02,124.73,125.82$, 126.34, 129.51, 137.06, 137.74, 142.21, 151.93, 159.60. trans ${ }^{13} \mathrm{C}-\mathrm{NMR}\left(100 \mathrm{MHz}, \mathrm{CDCl}_{3}\right): \delta 17.99$, $40.24,50.89,85.10,111.95,119.86,123.28,123.89,124.57,125.54,127.87,128.46,137.24,137.43$, 143.05, 151.54, 160.80. MS (ESI) $m / z 369.11[\mathrm{M}+\mathrm{H}]^{+}$, HRMS (ESI): calcd for $\mathrm{C}_{20} \mathrm{H}_{21} \mathrm{~N}_{2} \mathrm{OS} 2[\mathrm{M}+\mathrm{H}]^{+}$ 369.1095 found 369.1096 .

2-[5-(2,2'-Bithiophen-5-yl)-4-methyl-4,5-dihydroisoxazol-3-yl]pyridine (13). ${ }^{1} \mathrm{H}-\mathrm{NMR}\left(400 \mathrm{MHz}, \mathrm{CDCl}_{3}\right)$ : $\delta 1.53(\mathrm{~d}, J=7.1 \mathrm{~Hz}, 3 \mathrm{H}), 4.09(\mathrm{dq}, J=7.1 \mathrm{~Hz}, J=5.7 \mathrm{~Hz}, 1 \mathrm{H}), 5.50(\mathrm{dd}, J=5.6 \mathrm{~Hz}, J=0.5 \mathrm{~Hz}, 1 \mathrm{H})$, $6.98(\mathrm{dd}, J=5.1 \mathrm{~Hz}, J=3.6 \mathrm{~Hz}, 1 \mathrm{H}), 6.99(\mathrm{dd}, J=3.7 \mathrm{~Hz}, J=0.7 \mathrm{~Hz}, 1 \mathrm{H}), 7.02(\mathrm{~d}, J=3.7 \mathrm{~Hz}, 1 \mathrm{H}), 7.12$ $(\mathrm{dd}, J=3.6 \mathrm{~Hz}, J=1.1 \mathrm{~Hz}, 1 \mathrm{H}), 7.18(\mathrm{dd}, J=5.1 \mathrm{~Hz}, J=1.1 \mathrm{~Hz}, 1 \mathrm{H}), 7.29$ (ddd, $J=7.5 \mathrm{~Hz}$, $J=4.9 \mathrm{~Hz}, J=1.2 \mathrm{~Hz}, 1 \mathrm{H}), 7.72(\mathrm{td}, J=7.8 \mathrm{~Hz}, J=1.8 \mathrm{~Hz}, 1 \mathrm{H}), 8.04(\mathrm{dt}, J=8.0 \mathrm{~Hz}, J=1.0 \mathrm{~Hz}, 1 \mathrm{H})$, $8.61(\mathrm{ddd}, J=4.9 \mathrm{~Hz}, J=1.7 \mathrm{~Hz}, J=0.9 \mathrm{~Hz}, 1 \mathrm{H}) .{ }^{13} \mathrm{C}-\mathrm{NMR}\left(125 \mathrm{MHz}, \mathrm{CDCl}_{3}\right): \delta 17.63,50.30,86.34$, 122.51, 123.39, 124.00, 124.35, 124.71, 125.94, 127.88, 136.57, 137.10, 137.84, 142.02, 148.87, 149.35, 161.82. HRMS (EI): calcd for $\mathrm{C}_{17} \mathrm{H}_{14} \mathrm{~N}_{2} \mathrm{OSS}_{2}[\mathrm{M}+\mathrm{H}]^{+} 326.0548$ found 326.0555 .

2-Pyridinecarbonitrile Oxide Dimer (13a). ${ }^{1} \mathrm{H}-\mathrm{NMR}\left(400 \mathrm{MHZ}, \mathrm{CDCl}_{3}\right) \delta=7.32-7.35 \mathrm{ppm}(\mathrm{m}, 1 \mathrm{H}$, $\left.\mathrm{C}_{\text {Ar-H }}\right), 7.38-7.41\left(\mathrm{~m}, 1 \mathrm{H}, \mathrm{C}_{\mathrm{Ar}-\mathrm{H}}\right), 7.82-7.86\left(\mathrm{~m}, 3 \mathrm{H}, \mathrm{C}_{\mathrm{Ar}-\mathrm{H}}\right), 7.97$ (d, $\left.J=8.0 \mathrm{~Hz}, 1 \mathrm{H}, \mathrm{C}_{\mathrm{Ar}-\mathrm{H}}\right), 8.53(\mathrm{~d}$, $\left.J=4.6 \mathrm{~Hz}, 1 \mathrm{H}, \mathrm{C}_{\mathrm{Ar}-\mathrm{H}}\right), 8.56\left(\mathrm{~d}, J=4.8 \mathrm{~Hz}, 1 \mathrm{H}, \mathrm{C}_{\mathrm{Ar}-\mathrm{H}}\right) .{ }^{13} \mathrm{C}-\mathrm{NMR}\left(100 \mathrm{MHz}, \mathrm{CDCl}_{3}\right) \delta=114.6 \mathrm{ppm}$, 123.8, 124.3, 124.6, 125.0, 136.7, 136.8, 143.7, 146.8, 149.6, 149.7, $156.3\left(\mathrm{C}_{\mathrm{Ar}}\right) . \mathrm{MS}\left(\mathrm{ESI}^{+}\right) \mathrm{m} / z 240.0$ $[\mathrm{M}]^{+}, \mathrm{HRMS}\left(\mathrm{ESI}^{+}\right)$: calcd for $\mathrm{C}_{12} \mathrm{H}_{8} \mathrm{~N}_{4} \mathrm{O}_{2}[\mathrm{M}]^{+} 240.0647$ found 240.0642. IR (KBr): 3051, 2925, 2853, $1598,1567,1487,1403,1341,1285,1135,1090,993,965,827,792,749$. 


\subsection{Synthesis of 1,4-Bis(5-(2,2'-bithiophen-5-ylo)-4-methylisoxazoline-3-yl)benzene (14) under} High Pressure

A solution of $(E+Z)$ 5-(1-propenyl)-2,2'-bithiophene (10) $(536 \mathrm{mg}, 2.60 \mathrm{mmol})$ and terephthalobis(nitrile $\mathrm{N}$-oxide) (192 $\mathrm{mg}, 1.2 \mathrm{mmol})$ in $\mathrm{CH}_{2} \mathrm{Cl}_{2}(2 \mathrm{~mL})$ was placed in a Teflon capsule and heated at $100{ }^{\circ} \mathrm{C}$ for $4 \mathrm{~h}$ under pressure of $1 \mathrm{GPa}$. After that, volatile fractions were removed using a rotary evaporator. Crude product was purified using column chromatography $\left(\mathrm{SiO}_{2}, \mathrm{CH}_{2} \mathrm{Cl}_{2} /\right.$ hexane 1:3). Product 14 was obtained as an orange solid with 99\% yield. ${ }^{1} \mathrm{H}-\mathrm{NMR}\left(400 \mathrm{MHz}, \mathrm{CDCl}_{3}\right): \delta 7.77$ (s, 4H), $7.21(\mathrm{~d}, J=5.1 \mathrm{~Hz}, 2 \mathrm{H}), 7.13(\mathrm{~d}, J=3.4 \mathrm{~Hz}, 2 \mathrm{H}), 7.05-6.96(\mathrm{~m}, 6 \mathrm{H}), 5.50(\mathrm{~d}, J=5.0 \mathrm{~Hz}, 2 \mathrm{H})$, $3.84(\mathrm{dq}, J=6.9,5.4 \mathrm{~Hz}, 2 \mathrm{H}), 1.46(\mathrm{~d}, J=7.1 \mathrm{~Hz}, 6 \mathrm{H}) .{ }^{13} \mathrm{C}-\mathrm{NMR}\left(100 \mathrm{MHz}, \mathrm{CDCl}_{3}\right): \delta 160.14$, $160.13,141.77,137.87,136.94,130.14,127.88,127.57,125.99,124.77,124.04,123.30,86.08,50.23$, 17.62. HRMS (EI) calcd for $\mathrm{C}_{30} \mathrm{H}_{24} \mathrm{~S}_{4} \mathrm{~N}_{2} \mathrm{O}_{2}[\mathrm{M}]+572.0721$ found 572.0737.

\subsection{Synthesis of 3,5-Bis(2,2'-bithiophen-5-yl)-4-methylisoxazoline (15)}

To a stirred, cooled down to $-25{ }^{\circ} \mathrm{C}$ solution of 2,2'-bithiophene-5-carbox-imidoyl chloride $(2.37 \mathrm{~g}$, $9.72 \mathrm{mmol})$ and $(E+Z)$ 5-(1-propenyl)-2,2'-bithiophene (10) $(1.88 \mathrm{~g}, 9.19 \mathrm{mmol})$ in tetrahydrofuran $(250 \mathrm{~mL})$, triethylamine $(1.65 \mathrm{~mL}, 13.67 \mathrm{mmol})$ was added dropwise. After all amine was added, the reaction mixture was left to reach room temperature and the solvent was evaporated on a rotary evaporator. Crude product was purified using column chromatography $\left(\mathrm{SiO}_{2}, \mathrm{CHCl}_{3}\right)$. Product 15 was isolated with $60 \%$ yield as a yellow solid. ${ }^{1} \mathrm{H}-\mathrm{NMR}\left(400 \mathrm{MHz}, \mathrm{CDCl}_{3}\right): \delta 7.30(\mathrm{dd}, J=5.2 \mathrm{~Hz}$, $J=1.1 \mathrm{~Hz}, 1 \mathrm{H}), 7.27(\mathrm{dd}, J=3.6 \mathrm{~Hz}, J=1.1 \mathrm{~Hz}, 1 \mathrm{H}), 7.23(\mathrm{dd}, J=5.2 \mathrm{~Hz}, J=1.0 \mathrm{~Hz}, 1 \mathrm{H}), 7.21$ (d, $J=3.8 \mathrm{~Hz}, 1 \mathrm{H}), 7.16(\mathrm{dd}, J=3.7 \mathrm{~Hz}, J=1.5 \mathrm{~Hz}, 2 \mathrm{H}), 7.15(\mathrm{~d}, J=3.7 \mathrm{~Hz}, 2 \mathrm{H}), 7.07(\mathrm{dd}, J=5.1 \mathrm{~Hz}$, $J=3.7 \mathrm{~Hz}, 1 \mathrm{H}), 7.05(\mathrm{~d}, J=3.8 \mathrm{~Hz}, 1 \mathrm{H}), 7.02(\mathrm{dd}, J=5.1 \mathrm{~Hz}, J=3.7 \mathrm{~Hz}, 1 \mathrm{H}), 7.00(\mathrm{~d}, J=3.8 \mathrm{~Hz}$, $1 \mathrm{H}), 5.48(\mathrm{~d}, J=5.3 \mathrm{~Hz}, 1 \mathrm{H}), 3.78(\mathrm{qd}, J=7.1 \mathrm{~Hz}, J=5.3 \mathrm{~Hz}, 1 \mathrm{H}), 1.55(\mathrm{~d}, J=7.1 \mathrm{~Hz}, 3 \mathrm{H})$. ${ }^{13} \mathrm{C}-\mathrm{NMR}\left(125 \mathrm{MHz}, \mathrm{CDCl}_{3}\right): \delta 156.51,141.79,140.07,138.55,137.89,135.71,133.48,129.00$, $128.72,127.82,126.01,125.72,123.92,123.51,123.45,123.26,123.18,85.84,51.44,15.98 . \mathrm{HRMS}$ (ESI) calcd for $\mathrm{C}_{20} \mathrm{H}_{15} \mathrm{NOS} 4 \mathrm{Na}\left(\left[\mathrm{M}+\mathrm{Na}^{+}\right]\right.$: 435,99287 found 435,99415 .

\subsection{Synthesis of 5-(2,2'-Bithiophen-5-yl)-3-(2,6-dichlorophenyl)-4-methylisoxazole (16) and 3,5-Bis(2,2'-bithiophene-5-yl)-4-methylisoxazole (17)}

DDQ (575 mg, $2.54 \mathrm{mmol}$ ) was added to a solution of isoxazoline (11) (for product 16) or (15) (for product 17) $(1.27 \mathrm{mmol})$ in toluene $(140 \mathrm{~mL})$, and the reaction mixture was heated under reflux for $24 \mathrm{~h}$ and vigorously stirred. After that time, the product was still observed in the reaction mixture with TLC, thus two more loads of DDQ $(2 \times 575 \mathrm{mg}, 2 \times 2.54 \mathrm{mmol})$ were added at an interval of $24 \mathrm{~h}$ (the progress of the reaction was monitored with TLC). After $72 \mathrm{~h}$, the conversion was complete (TLC). Post-reaction mixture was concentrated to a small volume and loaded on a chromatography column ( $\mathrm{SiO}_{2}$, toluene). Products $\mathbf{1 6}$ and $\mathbf{1 7}$ were obtained with 95 and 90\% yields respectively, $\mathbf{1 6}$ as an orange-red solid, $\mathbf{1 7}$ as an orange solid.

5-(2,2'-Bithiophene-5-yl)-3-(2,6-dichlorophenyl)-4-methylisoxazole (16). ${ }^{1} \mathrm{H}-\mathrm{NMR}\left(400 \mathrm{MHz}, \mathrm{CDCl}_{3}\right)$ : $\delta 7.49-7.35(\mathrm{~m}, 3 \mathrm{H}), 7.29(\mathrm{dd}, J=5.1 \mathrm{~Hz}, J=1.2 \mathrm{~Hz}, 1 \mathrm{H}), 7.28(\mathrm{dd}, J=3.7 \mathrm{~Hz}, J=1.2 \mathrm{~Hz}, 1 \mathrm{H}), 7.24$ 
(d, $J=3.9 \mathrm{~Hz}, 1 \mathrm{H}), 7.19(\mathrm{dd}, J=5.1 \mathrm{~Hz}, J=1.2 \mathrm{~Hz}, 1 \mathrm{H}), 7.09(\mathrm{dd}, J=3.6 \mathrm{~Hz}, J=1.2 \mathrm{~Hz}, 1 \mathrm{H}), 7.06$ $(\mathrm{dd}, J=5.1 \mathrm{~Hz}, J=3.7 \mathrm{~Hz}, 1 \mathrm{H}), 7.00(\mathrm{~d}, J=3.7 \mathrm{~Hz}, 1 \mathrm{H}), 6.98(\mathrm{dd}, J=5.1 \mathrm{~Hz}, J=3.6 \mathrm{~Hz}, 1 \mathrm{H}), 2.69$ (s, 1H), 2.09 (s, 3H). ${ }^{13} \mathrm{C}-\mathrm{NMR}\left(100 \mathrm{MHz}, \mathrm{CDCl}_{3}\right): \delta 160.88,139.80,136.38,135.98,131.32,128.17$, 128.10, 127.95, 127.72, 127.38, 125.46, 124.63, 124.23, 109.70, 77.35, 77.04, 76.72, 8.09. HRMS (EI) calcd for $\mathrm{C}_{18} \mathrm{H}_{11} \mathrm{~S}_{2} \mathrm{NOCl}_{2}[\mathrm{M}]^{+} 390.9659$ found 390.9663. m.p. $134.8 \pm 0.5^{\circ} \mathrm{C}$.

3,5-Bis(2,2'-bithiophene-5-yl)-4-methylisoxazole (17). ${ }^{1} \mathrm{H}-\mathrm{NMR}\left(400 \mathrm{MHz}, \mathrm{CDCl}_{3}\right): \delta 7.47$ (d, $J=3.9 \mathrm{~Hz}$, $1 \mathrm{H}), 7.44(\mathrm{~d}, J=3.8 \mathrm{~Hz}, 1 \mathrm{H}), 7.34-7.29(\mathrm{~m}, 2 \mathrm{H}), 7.26(\mathrm{~d}, J=3.9 \mathrm{~Hz}, 1 \mathrm{H}), 7.25(\mathrm{~d}, J=3.8 \mathrm{~Hz}, 1 \mathrm{H})$, 7.10-7.09 (m, 1H), 7.08 (dd, $J=5.3 \mathrm{~Hz}, J=3.5 \mathrm{~Hz}, 1 \mathrm{H}), 2.48$ (s, 3H). ${ }^{13} \mathrm{C}-\mathrm{NMR}\left(100 \mathrm{MHz}, \mathrm{CDCl}_{3}\right): \delta$ $157.95,139.89,139.52,136.60,136.33,128.90,128.29,128.09,128.02,127.74,127.57,126.33$, 125.49, 125.24, 124.66, 124.60, 124.16, 124.02, 107.81, 77.33, 77.01, 76.69, 9.27. HRMS (EI) calcd for $\mathrm{C}_{20} \mathrm{H}_{13} \mathrm{NOS}_{4}[\mathrm{M}]^{+} 410.9880$ found 410.9891 .

\subsection{Synthesis of1,4-Bis[5-(2,2'-bithiophen-5-yl)isoxazol-3-yl]benzene (18) under high pressure}

A solution of 5-ethynyl-2,2'-bithiophene (494 mg, $2.60 \mathrm{mmol}$ ) (4) and terephthalo-bis(nitrile $\mathrm{N}$-oxide) (192 mg, $1.2 \mathrm{mmol})$ in $\mathrm{CH}_{2} \mathrm{Cl}_{2}(2 \mathrm{~mL})$ was placed in a Teflon capsule and heated at $100{ }^{\circ} \mathrm{C}$ for $4 \mathrm{~h}$ under pressure of $1 \mathrm{GPa}$. After that, volatile fractions were removed using a rotary evaporator. Crude product was purified using column chromatography $\left(\mathrm{SiO}_{2}, \mathrm{CH}_{2} \mathrm{Cl}_{2} /\right.$ hexane 1:3). Product 18 was obtained as an orange solid with $99 \%$ yield.

\subsection{Synthesis of 8,9-Bis(2,2'-bithiophen-5-yl)-7,10-(diphenyl)fluoranthene (19) and 9-(2,2'-} Bithiophene-5-yl)-8-(5-ethynyl-2,2'-bithiophen-5-yl)-7,10-(diphenyl)fluoranthene (20)

1,8-Bis(phenylethynyl)naphthalene (11 $\mathrm{mg}, 0.03 \mathrm{mmol})$ and 5,5'-ethyne-1,2-diylbis(2,2'-bithiophene) (5) $(59 \mathrm{mg}, 0.17 \mathrm{mmol})$ for the synthesis of 19 or 5,5'-buta-1,3-diyne-1,4-diylbis(2,2'-bithiophene) (6) (61 mg, $0.16 \mathrm{mmol}$ ) for the synthesis of 20, and Wilkinson's catalyst ( $3 \mathrm{mg}, 0.003 \mathrm{mmol}$ ) were placed in a screw capped glass vial. Xylene $(3 \mathrm{~mL})$ was added, and the vial was tightly capped and placed in thermostated oil bath in $130{ }^{\circ} \mathrm{C}$ and stirred for $72 \mathrm{~h}$. After that, the vial was cooled down and xylene was evaporated on a rotary evaporator. Crude solid residue was purified on chromatography column $\left(\mathrm{SiO}_{2}\right)$ using petroleum ether (for 19) or hexane:dichloromethane 3:1 (for 20) as an eluent. Products 19 and 20 were obtained with 60 and 70\% yield, respectively. 19 as a yellow solid, 20 as a yellowish oil.

8,9-Bis(2,2'-bithiophene-5-yl)-7,10-(diphenyl)fluoranthene (19). ${ }^{1} \mathrm{H}-\mathrm{NMR}\left(400 \mathrm{MHz}, \mathrm{CDCl}_{3}\right): \delta 7.74$ (d, $J=8.2 \mathrm{~Hz}, 2 \mathrm{H}), 7.36-7.44(\mathrm{~m}, 10 \mathrm{H}), 7.29-7.33(\mathrm{~m}, 2 \mathrm{H}), 7.09(\mathrm{dd}, J=5.0 \mathrm{~Hz}, J=1.1 \mathrm{~Hz}, 2 \mathrm{H}), 6.95$ $(\mathrm{dd}, J=3.6 \mathrm{~Hz}, J=1.1 \mathrm{~Hz}, 2 \mathrm{H}), 6.90(\mathrm{dd}, J=4.9 \mathrm{~Hz}, J=3.6 \mathrm{~Hz}, 2 \mathrm{H}), 6.74$ (d, $J=3.7 \mathrm{~Hz}, 2 \mathrm{H}), 6.59$ (d, $J=7.1 \mathrm{~Hz}, 2 \mathrm{H}), 6.51(\mathrm{~d}, J=3.7 \mathrm{~Hz}, 2 \mathrm{H}) .{ }^{13} \mathrm{C}-\mathrm{NMR}\left(100 \mathrm{MHz}, \mathrm{CDCl}_{3}\right): \delta 139.84,139.49,138.65$, $137.98,137.86,137.71,136.13,133.89$, 133.44, 130.25, 129.90, 129.76, 128.57, 127.87, 127.70, 127.62 , 127.11, 123.84, 123.81, 123.21, 122.79. HRMS (EI) calcd for $\mathrm{C}_{44} \mathrm{H}_{26} \mathrm{~S}_{4}[\mathrm{M}]^{+} 682.0917$ found 682.0923.

9-(2,2'-Bithiophene-5-yl)-8-(5-ethynyl-2,2'-bithiophene-5-yl)-7,10-(diphenyl)fluoranthene (20). ${ }^{1} \mathrm{H}-\mathrm{NMR}$ (400 MHz, $\left.\mathrm{CDCl}_{3}\right): \delta 7.75(\mathrm{t}, J=7.7 \mathrm{~Hz}, 2 \mathrm{H}), 7.57-7.67(\mathrm{~m}, 5 \mathrm{H}), 7.40-7.48(\mathrm{~m}, 5 \mathrm{H}), 7.34-7.37(\mathrm{~m}, 1 \mathrm{H})$, $7.29-7.33(\mathrm{~m}, 1 \mathrm{H}), 7.18(\mathrm{dt}, J=5.0 \mathrm{~Hz}, J=1.0 \mathrm{~Hz}, 2 \mathrm{H}), 7.12(\mathrm{dd}, J=3.6 \mathrm{~Hz}, J=1.1 \mathrm{~Hz}, 1 \mathrm{H}), 7.02(\mathrm{dd}$, $J=3.6 \mathrm{~Hz}, J=1.2 \mathrm{~Hz}, 1 \mathrm{H}), 6.98-7.01(\mathrm{~m}, 2 \mathrm{H}), 6.96(\mathrm{dd}, J=5.0 \mathrm{~Hz}, J=3.6 \mathrm{~Hz}, 1 \mathrm{H})$, 
6.87-6.89 (m, 2H), $6.82(\mathrm{~d}, J=3.7 \mathrm{~Hz}, 1 \mathrm{H}), 6.59-6.61(\mathrm{~m}, 2 \mathrm{H}) .{ }^{13} \mathrm{C}-\mathrm{NMR}\left(100 \mathrm{MHz}, \mathrm{CDCl}_{3}\right): \delta$ $139.72,139.34,139.16,139.01,138.27,138.06,137.94,137.57,137.18,137.03,136.16,135.67$, $134.90,133.51,132.38,130.12,129.95,129.82,129.77,128.80,128.73,128.19,127.97,127.88$, $127.26,127.21,124.90,124.16,124.12,123.85,123.83,123.62,123.54,123.52,123.03,122.34$, 94.44, 91.96. HRMS (ESI) calcd for $\mathrm{C}_{46} \mathrm{H}_{27} \mathrm{~S}_{4}[\mathrm{M}+\mathrm{H}]^{+} 707.0996$ found 707.1010.

\subsection{Synthesis of Hexa(2,2'-bithiophen-5-yl)benzene (21)}

5,5'-Ethyne-1,2-diylbis(2,2'-bithiophene) $(5,50 \mathrm{mg}, 0.14 \mathrm{mmol})$ and Wilkinson's catalyst (13 $\mathrm{mg}$, $0.014 \mathrm{mmol})$ were placed in a screw capped glass vial. Xylene $(3 \mathrm{~mL})$ was added, and the vial was tightly capped and placed in a thermostated oil bath in $130{ }^{\circ} \mathrm{C}$ and was stirred for $72 \mathrm{~h}$. During that time, the precipitation of grey solid in the reaction mixture was observed. After heating, the vial was cooled down, and the precipitate was filtered. Crude solid residue was washed with xylene and diethyl ether, and dried overnight at room temperature. Product 21 was isolated with $40 \%$ yield as a grey solid. $1.1 \mathrm{~Hz}, 6 \mathrm{H}), 6.99$ (d, $J=3.7 \mathrm{~Hz}, 6 \mathrm{H}), 6.97$ (dd, $J=5.1 \mathrm{~Hz}, J=3.6 \mathrm{~Hz}, 6 \mathrm{H}), 6.77$ (d, $J=3.7 \mathrm{~Hz}, 6 \mathrm{H})$. ${ }^{13} \mathrm{C}-\mathrm{NMR}\left(125 \mathrm{MHz}, \mathrm{DMSO}-\mathrm{d}_{6}\right): \delta$ 138.01, 137.78, 136.53, 135.99, 131.06, 128.25, 125.32, 123.80 , 122.98. HRMS (EI) calcd for $\mathrm{C}_{54} \mathrm{H}_{30} \mathrm{~S}_{12}[\mathrm{M}]^{+} 1061.8996$ found 1061.8977 .

\subsection{Synthesis of 1-(2,2'-Bithiophen-5-yl)-4-octyl-1,2,3-triazole (22)}

A mixture of 5-iodo-2,2'-bithiophene (3, $0.29 \mathrm{~g}, 1 \mathrm{mmol})$, ethanol-water solution (4 mL, 7:3 v/v), sodium azide (130 mg, $2 \mathrm{mmol}), \mathrm{CuI}$ (19 mg, $0.1 \mathrm{mmol})$, sodium ascorbate (20 mg, $0.1 \mathrm{mmol})$, 1-decyne $(0.18 \mathrm{~mL}, 1 \mathrm{mmol})$ and $N, N^{\prime}$-dimethylethylenediamine $(20 \mu \mathrm{L}, 0.2 \mathrm{mmol})$ was vigorously stirred at $50{ }^{\circ} \mathrm{C}$ for $24 \mathrm{~h}$. After that time, the post-reaction mixture was cooled down to room temperature and $25 \%$ solution of ammonia $(10 \mathrm{~mL})$ and ethyl acetate $(15 \mathrm{~mL})$ were added. Organic layer was washed with water (3 times $15 \mathrm{~mL}$ ) and dried over anhydrous $\mathrm{MgSO}_{4}$. Volatile fractions were removed on a rotary evaporator and a solid residue was purified on chromatography column $\left(\mathrm{SiO}_{2}, \mathrm{CH}_{2} \mathrm{Cl}_{2}\right)$. Product 22 was obtained as a dark solid with $70 \%$ yield. ${ }^{1} \mathrm{H}-\mathrm{NMR}\left(400 \mathrm{MHz}, \mathrm{CDCl}_{3}\right): \delta 7.63(\mathrm{~s}, 1 \mathrm{H}), 7.22(\mathrm{dd}$, $J=5.2 \mathrm{~Hz}, J=1.1 \mathrm{~Hz}, 1 \mathrm{H}), 7.20(\mathrm{dd}, J=3.6 \mathrm{~Hz}, J=1.1 \mathrm{~Hz}, 1 \mathrm{H}), 7.09(\mathrm{~d}, J=4.0 \mathrm{~Hz}, 1 \mathrm{H}), 7.06(\mathrm{~d}$, $J=4.0 \mathrm{~Hz}, 1 \mathrm{H}), 7.05(\mathrm{dd}, J=5.1 \mathrm{~Hz}, J=3.6 \mathrm{~Hz}, 1 \mathrm{H}), 2.78(\mathrm{t}, J=7.7 \mathrm{~Hz}, 2 \mathrm{H}), 1.72(\mathrm{dt}, J=15.3 \mathrm{~Hz}$, $J=7.8 \mathrm{~Hz}, 2 \mathrm{H}), 1.32(\mathrm{~m}, 10 \mathrm{H}), 0.88(\mathrm{t}, J=6.8 \mathrm{~Hz}, 3 \mathrm{H}) .{ }^{13} \mathrm{C}-\mathrm{NMR}\left(100 \mathrm{MHz}, \mathrm{CDCl}_{3}\right): \delta 149.36$, 136.96, 136.19, 134.59, 128.12, 126.37, 124.53, 122.32, 119.79, 117.80, 31.96, 29.44, 29.42, 29.36, 29.32, 25.72, 22.77, 14.21. HRMS (ESI) calcd for $\mathrm{C}_{18} \mathrm{H}_{24} \mathrm{~N}_{3} \mathrm{~S}_{2}[\mathrm{M}+\mathrm{H}]^{+} 346.1412$ found 346.1412 .

\subsection{Synthesis of 1-Benzyl-4-(2,2'-bithiophen-5-yl)-1,2,3-triazole (23)}

A mixture of 5-(trimethylsilyl)ethynyl-2,2'-bithiophene $(150 \mathrm{mg}, 0.571 \mathrm{mmol})$, benzylazide (110 $\mathrm{mg}$, $0.857 \mathrm{mmol}), \mathrm{K}_{2} \mathrm{CO}_{3}(87 \mathrm{mg}, 0.063 \mathrm{mmol}), \mathrm{CuSO}_{4} \cdot 5 \mathrm{H}_{2} \mathrm{O}(110 \mathrm{mg}, 0.046 \mathrm{mmol})$, sodium ascorbate $(270 \mathrm{mg}, 1.37 \mathrm{mmol})$, pyridine $(0.6 \mathrm{~mL}, 7.46 \mathrm{mmol})$ and tert-butanol-water mixture $(14 \mathrm{~mL}, 1: 1 \mathrm{v} / \mathrm{v})$ was stirred at room temperature for $48 \mathrm{~h}$. After that time, $25 \%$ solution of ammonia $(10 \mathrm{~mL})$ and ethyl acetate $(15 \mathrm{~mL})$ was added. Organic layer was washed with water $(3 \times 15 \mathrm{~mL})$ and dried over anhydrous $\mathrm{MgSO}_{4}$. Volatile fractions were removed on a rotary evaporator and a solid residue was purified on chromatography column $\left(\mathrm{SiO}_{2}, \mathrm{CH}_{2} \mathrm{Cl}_{2} / \mathrm{CH}_{2} \mathrm{Cl}_{2}+5 \% \mathrm{MeOH}\right)$. Product 23 was obtained as 
a dark solid with $50 \%$ yield. ${ }^{1} \mathrm{H}-\mathrm{NMR}\left(400 \mathrm{MHz}, \mathrm{CDCl}_{3}\right): \delta 7.56(\mathrm{~s}, 1 \mathrm{H}), 7.43-7.37(\mathrm{~m}, 3 \mathrm{H}), 7.33-7.30$ $(\mathrm{m}, 2 \mathrm{H}), 7.23(\mathrm{~d}, J=8.8 \mathrm{~Hz}, 1 \mathrm{H}), 7.22(\mathrm{dd}, J=5.1 \mathrm{~Hz}, J=1.1 \mathrm{~Hz}, 1 \mathrm{H}), 7.18(\mathrm{dd}, J=3.6 \mathrm{~Hz}, J=1.1 \mathrm{~Hz}$, $1 \mathrm{H}), 7.11(\mathrm{~d}, J=3.8 \mathrm{~Hz}, 1 \mathrm{H}), 7.02(\mathrm{dd}, J=5.1 \mathrm{~Hz}, J=3.6 \mathrm{~Hz}, 1 \mathrm{H}) .{ }^{13} \mathrm{C}-\mathrm{NMR}\left(100 \mathrm{MHZ}, \mathrm{CDCl}_{3}\right) \delta$ 143.12 , 137.22, 137.09, 134.53, 131.69, 129.33, 129.01, 128.24, 128.02, 124.84, 124.68, 124.21, 123.98 119.04, 53.43. HRMS (ESI) calcd for $\mathrm{C}_{17} \mathrm{H}_{14} \mathrm{~N}_{3} \mathrm{~S}_{2}[\mathrm{M}+\mathrm{H}]^{+} 324.0629$ found 324.0629 .

\subsection{Synthesis of 1-Decyl-4-(2,2'-Bithiophen-5-yl)-1,2,3-triazole (24) under High Pressure}

A solution of 5-ethynyl-2,2'-bithiophene (4) (100 mg, $0.525 \mathrm{mmol})$ and decylazide (144 $\mathrm{mg}$, $0.788 \mathrm{mmol})$ in $\mathrm{CH}_{2} \mathrm{Cl}_{2}(2 \mathrm{~mL})$ was placed in a teflon capsule and heated at $80{ }^{\circ} \mathrm{C}$ for $24 \mathrm{~h}$ under pressure of $1 \mathrm{GPa}$. After that, volatile fractions were removed using a rotary evaporator. Crude product was purified using column chromatography $\left(\mathrm{SiO}_{2}, \mathrm{CH}_{2} \mathrm{Cl}_{2}\right)$. Product 24 was obtained as a dark solid with $60 \%$ yield. ${ }^{1} \mathrm{H}-\mathrm{NMR}\left(400 \mathrm{MHz}, \mathrm{CDCl}_{3}\right): \delta 7.65(\mathrm{~s}, 1 \mathrm{H}), 7.26(\mathrm{~d}, J=3.8 \mathrm{~Hz}, 1 \mathrm{H}), 7.22(\mathrm{dd}$, $J=5.1 \mathrm{~Hz}, J=1.1 \mathrm{~Hz}, 1 \mathrm{H}), 7.20(\mathrm{dd}, J=3.6 \mathrm{~Hz}, J=1.1 \mathrm{~Hz}, 1 \mathrm{H}), 7.13(\mathrm{~d}, J=3.8 \mathrm{~Hz}, 1 \mathrm{H}), 7.02(\mathrm{dd}$, $J=5.1 \mathrm{~Hz}, J=3.6 \mathrm{~Hz}, 1 \mathrm{H}), 4.36(\mathrm{t}, J=7.2 \mathrm{~Hz}, 2 \mathrm{H}), 1.93(\mathrm{~m}, 2 \mathrm{H}), 1.29(\mathrm{~m}, 14 \mathrm{H}), 0.87(\mathrm{t}, J=6.8 \mathrm{~Hz}$, $3 \mathrm{H}) .{ }^{13} \mathrm{C}-\mathrm{NMR}\left(100 \mathrm{MHz}, \mathrm{CDCl}_{3}\right): \delta 142.57,137.27,136.93,131.96,127.99,124.66,124.62,124.21$, 123.92, 118.99, 50.63, 31.95, 30.39, 29.56, 29.48, 29.35, 29.10, 26.58, 22.76, 14.20. HRMS (ESI) calcd for $\mathrm{C}_{20} \mathrm{H}_{28} \mathrm{~N}_{3} \mathrm{~S}_{2}[\mathrm{M}+\mathrm{H}]^{+} 374.1725$ found 374.1727 .

\subsection{Synthesis of 1-Decyl-4,5-bis(2,2'-bithiophen-5-yl)-1,2,3-triazole (25)}

The mixture of decylazide (61 mg, $0.33 \mathrm{mmol}), \mathrm{bbta}(5)(150 \mathrm{mg}, 0.42 \mathrm{mmol})$, benzene $(7 \mathrm{~mL})$ and $\left[\mathrm{RuCl}(\mathrm{cp})\left(\mathrm{PPh}_{3}\right)_{2}\right](8 \mathrm{mg}, 0.011 \mathrm{mmol})$ was stirred at $80{ }^{\circ} \mathrm{C}$ for $24 \mathrm{~h}$. After that, volatile fractions were removed using a rotary evaporator. Crude product was purified using column chromatography $\left(\mathrm{SiO}_{2}\right.$, hexane:ethyl acetate 9:1). Product 25 was obtained as a dark solid with 60\% yield. ${ }^{1} \mathrm{H}-\mathrm{NMR}$ (400 $\mathrm{MHz}, \mathrm{CDCl}_{3}$ ): $\delta 7.31$ (dd, $\left.J=5.1 \mathrm{~Hz}, J=1.1 \mathrm{~Hz}, 1 \mathrm{H}\right), 7.29$ (d, $\left.J=3.7 \mathrm{~Hz}, 1 \mathrm{H}\right), 7.27$ (dd, $J=3.6 \mathrm{~Hz}$, $J=1.1 \mathrm{~Hz}, 1 \mathrm{H}), 7.20(\mathrm{dd}, J=5.1 \mathrm{~Hz}, J=1.1 \mathrm{~Hz}, 1 \mathrm{H}), 7.16(\mathrm{dd}, J=3.6 \mathrm{~Hz}, J=1.1 \mathrm{~Hz}, 1 \mathrm{H})$, $7.13-7.11(\mathrm{~m}, 2 \mathrm{H}), 7.07$ (dd, $J=5.1 \mathrm{~Hz}, J=3.6 \mathrm{~Hz}, 1 \mathrm{H}), 7.04$ (d, $J=3.8 \mathrm{~Hz}, 1 \mathrm{H}), 6.99$ (dd, $J=5.1 \mathrm{~Hz}$, $J=3.6 \mathrm{~Hz}, 1 \mathrm{H}), 4.28(\mathrm{~m}, 2 \mathrm{H}), 1.87(\mathrm{~m}, 2 \mathrm{H}), 1.26(\mathrm{~m}, 14 \mathrm{H}), 0.86(\mathrm{t}, J=6.8 \mathrm{~Hz}, 3 \mathrm{H}) .{ }^{13} \mathrm{C}-\mathrm{NMR}$ $\left(100 \mathrm{MHz}, \mathrm{CDCl}_{3}\right): \delta 141.99,141.71,137.49,137.27,136.24,131.94,131.63,128.23,127.98,125.69$, 125.66, 125.56, 124.91, 124.66, 124.33, 124.26, 124.15, 124.08, 48.88, 31.99, 30.44, 29.60, 29.48, 29.40, 29.07, 26.59, 22.79, 14.25. HRMS(EI) calcd for $\mathrm{C}_{28} \mathrm{H}_{31} \mathrm{~N}_{3} \mathrm{~S}_{4}[\mathrm{M}]^{+} 537.14009$ found: 537.13955.

3.17. Synthesis of $N$-phenyl-2,5-bis(2,2'-bithiophen-5-yl)pyrrole (26), $N$-(p-decyloxy)phenyl-2,5-bis(2,2'bithiophen-5-yl)pyrrole (27) and N-(2-carbazolylethyl)-2,5-bis(2,2'-bithiophen-5-yl)pyrrole (28)

A mixture of 1,4-bis(2,2'-bithiophen-5-yl)buta-1,3-diyne $(6,50 \mathrm{mg}, 0.132 \mathrm{mmol}), \mathrm{CuCl}(1.31 \mathrm{mg}$, $0.0132 \mathrm{mmol}$ ) and aniline $(0.12 \mathrm{~mL}, 1.32 \mathrm{mmol})$ (for 26) or $p$-(decyloxyphenyl)aniline (330 $\mathrm{mg}$, $2.64 \mathrm{mmol}$ ) (for 27) or $\mathrm{N}$-ethyl-3-aminocarbazole (560 mg, $2.64 \mathrm{mmol}$ ) (for 28 ) was stirred at $110{ }^{\circ} \mathrm{C}$ for $48 \mathrm{~h}$. After that time, post-reaction mixture was cooled down to room temperature and $\mathrm{CH}_{2} \mathrm{Cl}_{2}$ $(50 \mathrm{~mL})$ was added. Mixture was filtered and the filtrate was washed with $0.5 \mathrm{M}$ solution of $\mathrm{NaCN}$ in water $(3 \times 20 \mathrm{~mL})$. The organic layer was dried over anhydrous $\mathrm{MgSO}_{4}$ and volatile fractions were removed using a rotary evaporator. Crude residue was dissolved in hexane: $\mathrm{CH}_{2} \mathrm{Cl}_{2}$ mixture $(5: 1)$ and 
loaded on chromatography column $\left(\mathrm{SiO}_{2}\right)$. Compounds 26, 27 and 28 were isolated as yellow solids with 30, 31 and 74\% yield, respectively. For the isolation of pure products, the following eluents were used: hexane: $\mathrm{CH}_{2} \mathrm{Cl}_{2}(5: 1)$ for $\mathbf{2 6}$ and $\mathbf{2 7}$; hexane: $\mathrm{CHCl}_{3}(5: 2)$ with $1 \%$ of triethylamine for $\mathbf{2 8}$.

N-phenyl-2,5-bis(2,2'-bithiophene-5-yl)pyrrole (26). ${ }^{1} \mathrm{H}-\mathrm{NMR}\left(400 \mathrm{MHz}, \mathrm{CDCl}_{3}\right): \delta 7.51$ (m, 3H), 7.40 $(\mathrm{dd}, J=8.1 \mathrm{~Hz}, J=1.4 \mathrm{~Hz}, 2 \mathrm{H}), 7.17(\mathrm{dd}, J=5.1 \mathrm{~Hz}, J=1.1 \mathrm{~Hz}, 2 \mathrm{H}), 7.06(\mathrm{dd}, J=3.6 \mathrm{~Hz}, J=1.1 \mathrm{~Hz}$, 2H), $6.98(\mathrm{dd}, J=5.1 \mathrm{~Hz}, J=3.6 \mathrm{~Hz}, 2 \mathrm{H}), 6.89$ (d, $J=3.8 \mathrm{~Hz}, 2 \mathrm{H}), 6.60$ (s, 2H), 6.36 (d, $J=3.8 \mathrm{~Hz}, 2 \mathrm{H})$. ${ }^{13} \mathrm{C}-\mathrm{NMR}\left(100 \mathrm{MHz}, \mathrm{CDCl}_{3}\right): \delta 138.44,137.42,135.67,133.88,130.25,130.10,129.63,129.56,127.89$, 124.72, 124.23, 123.90, 123.45, 110.24. HRMS (EI) calcd for $\mathrm{C}_{26} \mathrm{H}_{17} \mathrm{NS}_{4}[\mathrm{M}]^{+} 471.0244$ found 471.02434 .

$\mathrm{N}$-(p-decyloxy)phenyl-2,5-bis(2,2'-bithiophene-5-yl)pyrrole (27). ${ }^{1} \mathrm{H}-\mathrm{NMR}$ (400 $\left.\mathrm{MHz}, \mathrm{CDCl}_{3}\right): \delta 7.27$ (m, 2H), $7.15(\mathrm{dd}, J=5.1 \mathrm{~Hz}, J=1.1 \mathrm{~Hz}, 2 \mathrm{H}), 7.04(\mathrm{dd}, J=3.6 \mathrm{~Hz}, J=1.1 \mathrm{~Hz}, 2 \mathrm{H}), 6.97$ (m, 4H), 6.88 $(\mathrm{d}, J=3.8 \mathrm{~Hz}, 2 \mathrm{H}), 6.56(\mathrm{~s}, 2 \mathrm{H}), 6.40(\mathrm{~d}, J=3.8 \mathrm{~Hz}, 2 \mathrm{H}), 4.03(\mathrm{t}, J=6.6 \mathrm{~Hz}, 2 \mathrm{H}), 1.84(\mathrm{~m}, 2 \mathrm{H}), 1.33$ $(\mathrm{s}, 15 \mathrm{H}), 0.88(\mathrm{t}, J=6.6 \mathrm{~Hz}, 3 \mathrm{H}) .{ }^{13} \mathrm{C}-\mathrm{NMR}\left(100 \mathrm{MHz}, \mathrm{CDCl}_{3}\right): \delta 160.04,137.53,135.50,134.11,131.07$, 130.76, 130.55, 127.88, 124.48, 124.17, 123.96, 123.42, 115.32, 109.88, 68.57, 32.06, 29.74, 29.72, 29.59, 29.48, 29.37, 26.21, 22.83, 14.26. HRMS (EI) calcd for $\mathrm{C}_{36} \mathrm{H}_{37} \mathrm{NOS}_{4}[\mathrm{M}]^{+} 627.1758$ found 627.1757 .

$\mathrm{N}$-(2-carbazolylethyl)-2,5-bis(2,2'-bithiophen-5-yl)pyrrole (28). ${ }^{1} \mathrm{H}-\mathrm{NMR}\left(400 \mathrm{MHz}, \mathrm{CDCl}_{3}\right): \delta 8.12$ $(\mathrm{d}, J=1.8 \mathrm{~Hz}, 1 \mathrm{H}), 8.05(\mathrm{~d}, J=7.8 \mathrm{~Hz}, 1 \mathrm{H}), 7.50(\mathrm{~m}, 5 \mathrm{H}), 7.09(\mathrm{dd}, J=5.1 \mathrm{~Hz}, J=1.1 \mathrm{~Hz}, 2 \mathrm{H}), 6.94$ $(\mathrm{dd}, J=3.6 \mathrm{~Hz}, J=1.1 \mathrm{~Hz}, 2 \mathrm{H}), 6.90(\mathrm{dd}, J=5.0 \mathrm{~Hz}, J=3.6 \mathrm{~Hz}, 2 \mathrm{H}), 6.77$ (d, $J=3.9 \mathrm{~Hz}, 2 \mathrm{H}), 6.63$ (s, 2H), $6.30(\mathrm{~d}, J=3.9 \mathrm{~Hz}, 2 \mathrm{H}), 4.46(\mathrm{q}, J=7.2 \mathrm{~Hz}, 2 \mathrm{H}), 1.53(\mathrm{t}, J=7.2 \mathrm{~Hz}, 3 \mathrm{H}) .{ }^{13} \mathrm{C}-\mathrm{NMR}(100 \mathrm{MHz}$, $\left.\mathrm{CDCl}_{3}\right): \delta 140.88,140.17,137.49,135.15,134.47,130.98,129.56,127.80,127.22,126.57,124.22$, 124.04, 124.00, 123.57, 123.33, 122.83, 122.16, 121.16, 119.52, 109.74, 109.11, 109.05, 38.07, 14.05 . HRMS (EI) calcd for $\mathrm{C}_{34} \mathrm{H}_{24} \mathrm{~N}_{2} \mathrm{~S}_{4}[\mathrm{M}]^{+} 588.0822$ found 588.0837 .

\section{Conclusions}

This work reports several highly effective new catalytically or high-pressure-activated reactions and routes leading to diverse 2,2'-bithiophene derivatives. New Pd/Cu-mediated coupling reactions, $\mathrm{Mn}-$, $\mathrm{Rh}$-, $\mathrm{Cu}$ - or Ru-catalyst mediated various type of cycloaddition, $\mathrm{Ru}$-complex or 15 -crown-5/NaOH promoted double bond migration in allylic systems and $\mathrm{Cu} / \mathrm{NEt}_{3}$-mediated complexation of metal centre were presented. Thanks to these new catalytic reactions and catalytic routes (combined with non-catalytic processes), we obtained novel acetylene, butadiyne, isoxazole, 1,2,3-triazole, pyrrole, benzene and fluoranthene derivatives bearing one, two or six 2,2'-bithiophen-5-yl (bt) moieties. The obtained compounds are of general formulas: bt-A, bt-A-bt and (bt) ${ }_{6} \mathrm{~A}$, where 2,2'-bithiophen-5-ylic fragments are connected by $-\mathrm{C} \equiv \mathrm{C}-,-\mathrm{C} \equiv \mathrm{C}-\mathrm{C} \equiv \mathrm{C}-$, aryl and heteroaryl. The "first generation" substrate containing bithiophene motif was 5-lithio-2,2'-bithiophene, which was converted into 5-iodo- and 5-allyl-2,2'bithiophenes ("the second generation" substrate). In the next step, the above mentioned compounds were transformed catalytically to 5-ethynyl-2,2'-bithiophene, 1,2-bis(2,2'-bithiophene-5-yl)acetylene, 5-(1-propenyl)-2,2'-bithiophene, and 1,4-bis(2,2'-bithiophene-5-yl)buta-1,3-diyne ("the third generation" substrates). Moreover, in situ generated 2,2'-bithiophen-5-carbonitrile oxide and 2,2'-bithiophen-5-yl azide belonging to the third-generation substrates were used. For the synthesis of 1,2-bis(2,2'-bithiophene-5yl)acetylene and 1,4-bis(2,2'-bithiophene-5-yl)buta-1,3-diyne gaseous acetylene and butadiyne and very 
effective cascade reactor systems were used. All the obtained compounds including bithiophene motif can be applied in organic electronics as monomers for new conducting polythiophenes or as luminescence materials. Moreover, some of them, for instance triazole derivatives, can play the role of cyclometalated ligands, while others should interest scientists searching for new medical probes and pharmaceutics, i.e., antifungal ones. Our preliminary examination, presented in the supporting information, has shown that some of the obtained compounds have very interesting luminescence properties and the derivatives which contain at least two bt motifs can be easily electropolymerized into conducting polymers.

\section{Supplementary Materials}

Supplementary materials can be accessed at: http://www.mdpi.com/1420-3049/20/03/4565/s1.

\section{Acknowledgments}

This work was supported by National Science Centre of Poland, Projects No.: DEC-011/01/B/ST5/06309 and DEC-2012/05/N/ST5/00733, and by The National Centre of Research and Development, Project No. PBS2/A5/40/2014. Moreover, J. Malarz acknowledges a scholarship from the TWING project co-financed by the European Social Fund. S. Kula acknowledges a scholarship from the Forszt project co-financed by the European Social Fund. I. Grudzka-Flak, M. Filapek, G. Szafraniec-Gorol, B. Marcol, M. Matussek, A. Szlapa acknowledge a scholarships from the DoktoRIS project co-financed by the European Social Fund.

\section{Author Contributions}

Stanisław Krompiec wrote the manuscript, developed the main idea of the work; Michał Filapek performed electrochemical measurements, synthesized isoxazoles, co-author of the main idea of the work; Iwona Grudzka-Flak synthesized pyrroles; Aneta Słodek wrote the experimental part, co-author of the main idea of the work; Sławomir Kula synthesized benzene derivatives via Mn catalysis; Jan Grzegorz Malecki performed X-ray measurements and calculations; Joanna Malarz synthesized isoxazolines; Grażyna Szafraniec-Gorol synthesized triazoles; Mateusz Penkala performed [2 + $2+2]$ cycloaddition reactions; Ewa Schab-Balcerzak co-author of the main idea of the work; Marian Paluch performed reactions under high pressure; Michał Mierzwa performed reactions under high pressure; Marek Matussek synthesized bis(bithienyl) derivatives of acetylene and buta-1,3-diyne; Agata Szłapa performed NMR measurements and analysis; Michał Pająk synthesized some of the isoxazolines and isoxazoles; Dariusz Błach performed aromatization of dihydroisoxazolines; Beata Marcol performed isomerisation of allyl precursors; Witold Danikiewicz performed MS and HRMS measurements and analysis; Bartosz Boharewicz co-author of part devoted to preliminary examination of novel 2,2'-bithiophene derivatives in organic electronics; Agnieszka Iwan co-author of part devoted to preliminary examination of novel 2,2'-bithiophene derivatives in organic electronics. All authors discussed the results and commented on the manuscript.

\section{Conflicts of Interest}

The authors declare no conflict of interest. 


\section{References}

1. Mishra, A.; Ma Ch, Q.; Bäuerle P. Functional Oligothiophenes: Molecular Design for Multidimensional Nanoarchitectures and Their Applications. Chem. Rev. 2009, 109, 1141-1276.

2. Agarwal, N.; Nayak, P.K.; Ali, F.; Patankar, M.P.; Narasimhan, K.L. Tuning of HOMO levels of carbazole derivatives: New molecules for blue OLED. Synth. Met. 2011, 161, 466-473.

3. Hung, W.Y.; Chi, L.C.; Chen, W.J.; Chen, Y.M.; Chou, S.H.; Wong, K.T. A new benzimidazole/ carbazole hybrid bipolar material for highly efficient deep-blue electrofluorescence, yellow-green electrophosphorescence, and two-color-based white OLEDs. J. Mater. Chem. 2010, 20, 10113-10119.

4. Lin, Y.; Li Y.; Zhan, X. Small molecule semiconductors for high-efficiency organic photovoltaics. Chem. Soc. Rev. 2012, 41, 4245-4272.

5. Letizia, J.A.; Rivnay, J.; Facchetti, A.; Ratner, M.A.; Marks, T.J. Variable Temperature Mobility Analysis of n-Channel, p-Channel, and Ambipolar Organic Field-Effect Transistors. Adv. Funct. Mater. 2010, 20, 50-58.

6. Hung, W.I.; Liao, Y.Y.; Hsu, C.Y.; Chou, H.H.; Lee, T.H.; Kao, W.S.; Lin, J.T. High-Performance Dye-Sensitized Solar Cells Based on Phenothiazine Dyes Containing Double Anchors and Thiophene Spacers. Chem. Asian J. 2014, 9, 357-366.

7. Li, C.; Liu, M.; Pschirer, N.G.; Baumgarten, M.; Mullen, K. Polyphenylene-Based Materials for Organic Photovoltaics. Chem. Rev. 2010, 110, 6817-6855.

8. Cui, M.C.; Li, Z.J.; Tang, R.K.; Liu, B.L. Synthesis and evaluation of novel benzothiazole derivatives based on the bithiophene structure as potential radiotracers for $\beta$-amyloid plaques in Alzheimer's disease. Bioorg. Med. Chem. 2010, 18, 2777-2784.

9. Tsai, P.I.; Lee, S.S.; Chou, S.T.; Jan, C.M.; Chang, Y.T.; Lee, A.S. Y.; Lee, C.K. A sensitive bithiophene-based biosensor for interferon-gamma characterization and analysis. Thin Solid Films 2014, in press.

10. Cui, M.; Li, Z.; Tang, R.; Jia, H.; Liu, B. Novel (E)-5-styryl-2,2'-bithiophene derivatives as ligands for $\beta$-amyloid plaques. Eur. J. Med. Chem. 2011, 46, 2908-2916.

11. Martínez, M.M.; Peña-López, M.; Sestelo, J.P.; Sarandeses, L.A. Synthesis of functionalized thiophenes and oligothiophenes by selective and iterative cross-coupling reactions using indium organometallics. Org. Biomol. Chem. 2012, 10, 3892-3898.

12. Kato, S.; Shimizu, S.; Taguchi, H.; Kobayashi, A.; Tobita, S.; Nakamura, Y. Synthesis and Electronic, Photophysical, and Electrochemical Properties of a Series of Thienylcarbazoles. J. Org. Chem. 2012, 77, 3222-3232.

13. Potratz, S.; Mishra, A.; Bäuerle, P. Thiophene-based donor-acceptor co-oligomers by copper-catalyzed 1,3-dipolar cycloaddition. Beilstein J. Org. Chem. 2012, 8, 683-692.

14. Krompiec, S.; Krompiec, M.; Filapek, M.; Flak, T.; Grudzka, I.; Zemlak, K.; Jezierski, Z. Method for the synthesis of 5-alkynyl-2,2'-bithiophenes by using coupling of the preparate containing 5-iodo-2,2'-bitiophene with terminal acetylenes. Appl. No.: P.399817, 5 July 2012.

15. Krompiec, S.; Grudzka, I.; Zych, D. Method for the synthesis of 1,4-bis(2,2'-bithiophene-5-yl)1,3-butadiyne. Appl. No.: P.404279, 10 June 2013.

16. Liu, W.; Pink, M.D.; Lee, D. Conjugated Polymer Sensors Built on $\pi$-Extended Borasiloxane Cages. J. Am. Chem. Soc. 2009, 131, 8703-8707. 
17. Yam, V.W.; Cheung, K.L.; Yip, S.K.; Cheung, K.K. Synthesis, characterization, structure and luminescence studies of mono-, di- and trinuclear gold(I) phosphine alkynyl complexes. J. Organomet. Chem. 2003, 681, 196-209.

18. Abbotto, A.; Bradamante, S.; Facchetti, A.; Pagani, G.A. Regioselective Synthesis of Highly Solvatochromic Thiophene-Spaced N-Alkylpyridinium Dicyanomethanides for Second-Harmonic Generation. J. Org. Chem. 1997, 62, 5755-5765.

19. Krompiec, S.; Kuźnik, N.; Krompiec, M.; Penczek, R.; Mrzigod, J.; Tórz, A. The role of the functional group in double bond migration in allylic systems catalysed by ruthenium hydride complexes. J. Mol. Catal. A Chem. 2006, 253, 132-146.

20. Brorson, M.; King, J.D.; Kiriakidou, K.; Prestopino, F.; Nordlander, E. Metal Cluster in Chemistry; Wiley-VCH: Weinheim, Germany, 1999; pp. 741-781.

21. Landman, M.; Waldbach, T.; Gorls, H.; Lotz, S. Titanium complexes of $\pi$-coordinated thiophene derivatives. J. Organomet. Chem. 2003, 678, 5-14.

22. Lockemeyer, J.R.; Rauchfuss, T.B.; Rheingold, A.L.; Wilson, S.R. (Tetramethylthiophene)ruthenium Dichloride Dimer: A Versatile Synthetic Intermediate in Thiophene Coordination Chemistry. J. Am. Chem. Soc. 1989, 111, 8828-8834.

23. Uddin, M.N.; Mottalib, M.A.; Begum, N.; Ghosh, S.; Raha, A.K.; Haworth, D.T.; Lindeman, S.V.; Siddiquee, T.A.; Bennett, D.W.; Hogarth, G.; et al. Carbon-Phosphorus Bond Activation of Tri(2-thienyl)phosphine at Dirhenium and Dimanganese Centers. Organometallics 2009, 28, $1514-1523$.

24. Sanger, M.J.; Angelici, R.J. Dynamic NMR Studies of the Restricted Rotation of Thiophenes (Th) and Selenophenes $(\mathrm{Seln})$ in the $\mathrm{Cr}(\mathrm{CO})_{3}\left(\eta^{5}-\mathrm{Th}\right)$ and $\mathrm{Cr}(\mathrm{CO})_{3} \quad \eta^{5}$-Seln) Complexes. Organometallics 1994, 13, 1821-1831.

25. Ganja, E.A.; Rauchfuss, T.M.; Stern, C.L. The chemistry of (ring)Ru ${ }^{2+}$ (ring = tetramethylthiophene, p-cymene). Organometallics 1991, 10, 270-275.

26. Krompiec, M.; Krompiec, S.; Ignasiak, H.; Łapkowski, M.; Kuś, P.; Stanek, Ł.; Penczek, R.; Lis, S.; Staniński, K.; Sajewicz, M.; et al. Synthesis and electropolymerization of 3,5-dithienylpyridines, their complexes and N-methylpyridinium cations. Synth. Met. 2008, 158, 831-838.

27. Krompiec, M.; Krompiec, S.; Grudzka, I.; Filapek, M.; Skórka, Ł.; Flak, T.; Łapkowski, M. A cross-linked conjugated metallopolymer comprised of bisaxially coordinated ruthenium tetra-t-butyl phthalocyanine connected by quaterthiophene linkers. Electrochim. Acta 2011, 56, 6824-6830.

28. Data, P.; Zassowski, P.; Lapkowski, M.; Domagała, W.; Krompiec, S.; Flak, T.; Penkala, M.; Swist, A.; Soloducho, J.; Danikiewicz, W. Electrochemical and spectroelectrochemical comparison of alternated monomers and their copolymers based on carbazole and thiophene derivatives. Electrochim. Acta 2014, 122, 118-129.

29. Krompiec, S.; Filapek, M.; Grudzka, I.; Kula, S.; Słodek, A.; Skórka, Ł.; Danikiewicz W.; Ledwon, P.; Lapkowski, M. An ambipolar behavior of novel ethynyl-bridged polythiophenes-A comprehensive study. Synth. Met. 2013, 165, 7-16.

30. Krompiec, S.; Krompiec, M.; Filapek, M.; Flak, T.; Grudzka, I.; Zemlak, K.; Jezierski, Z. Method for the synthesis of the preparate containing 5-lithio-2,2'-bithiophene. Appl. No.: P.399815, 5 July 2012.

31. Krompiec, S.; Krompiec, M.; Filapek, M.; Flak, T.; Grudzka, I.; Zemlak, K.; Jezierski, Z. Method for the synthesis of the preparate containing 5-iodo-2,2'-bithiophene Appl. No.: P.399816, 5 July 2012. 
32. Chuentragool, P.; Vongnam, K.; Rashatasakhon, P.; Sukwattanasinitt, M.; Wacharasindhu, S. Calcium carbide as a cost-effective starting material for symmetrical diarylethynes via Pd-catalyzed coupling reaction. Tetrahedron 2011, 67, 8177-8182.

33. Bertrand, G.H.V.; Tortech, L.; Gandon, V.; Aubert, C.; Fichou, D. Synthesis and photovoltaic performances in solution-processed BHJs of oligothiophene-substituted organocobalt complexes $\left[\left(\eta^{4}-\mathrm{C}_{4}(n \mathrm{~T}) 4\right) \mathrm{Co}\left(\eta^{5}-\mathrm{C}_{5} \mathrm{H}_{5}\right)\right]$. Chem. Commun. 2014, 50, 8663-8866.

34. Kagan, J.; Arora, S.K. Synthesis of alpha-thiophene oligomers via 1,3-butadiynes. J. Org. Chem. 1983, 48, 4317-4320.

35. Merkul, E.; Urselmann, D.; Müller, T.J.J. Consecutive One-Pot Sonogashira-Glaser Coupling Sequence-Direct Preparation of Symmetrical Diynes by Sequential $\mathrm{Pd} / \mathrm{Cu}$ Catalysis. Eur. J. Org. Chem. 2011, 238-242.

36. Trotus, I.T.; Zimmermann, T.; Schüth, F. Catalytic Reactions of Acetylene: A Feedstock for the Chemical Industry Revisited. Chem. Rev. 2014, 114, 1761-1782.

37. Holmes, A.B.; Sporikou, C.N. Trimethylsilylacetylene. Org. Synth. 1987, 65, 61-67.

38. McCormick, T.M.; Jahnke, A.A.; Lough, A.J.; Seferos, D.S. Tellurophenes with Delocalized $\pi$-Systems and Their Extended Valence Adducts. J. Am. Chem. Soc. 2012, 134, 3542-3548.

39. Yoshikai, N.; Zhang, S.L.; Yamagata, K.; Tsuji, H.; Nakamura, E. Mechanistic Study of the Manganese-Catalyzed [2+2+2] Annulation of 1,3-Dicarbonyl Compounds and Terminal Alkynes. J. Am. Chem. Soc. 2009, 131, 4099-4109.

40. Kuninobu, Y.; Nishi, M.; Kawata, A.; Takata, H.; Hanatani, Y.; Yudha, S.S.; Iwai, A.; Takai, K. Rhenium- and Manganese-Catalyzed Synthesis of Aromatic Compounds from 1,3-Dicarbonyl Compounds and Alkynes. J. Org. Chem. 2010, 75, 334-341.

41. Broere, D.L.J.; Ruijter, E. Recent Advances in Transition-Metal-Catalyzed $[2+2+2]-$ Cyclo(co)trimerization Reactions. Synthesis 2012, 44, 2639-2672.

42. Savage, G.P. Spiro Isoxazolines via Nitrile Oxide 1,3-Dipolar Cycloaddition Reactions. Curr. Org. Chem. 2010, 14, 1478-1499.

43. Minakata, S.; Okumura, S.; Nagamachi, T.; Takeda, Y. Generation of Nitrile Oxides from Oximes Using t-BuOI and Their Cycloaddition. Org. Lett. 2011, 13, 2966-2969.

44. Easton, C.J.; Hughes, C.M.M.; Savage, G.P.; Simpson, G.W. Cycloaddition Reactions of Nitrile Oxides with Alkenes; Academic Press: San Diego, CA, USA, 1994; Volume 60, pp. 261-327.

45. Jager, V.; Colinas, P.A. Synthetic Applications of 1,3-Dipolar Cycloaddition Chemistry Toward Heterocycles and Natural Products; Wiley \& Sons: New York, NY, USA, 2002; pp. 361-472.

46. Bujak, P.; Krompiec, S.; Malarz, J.; Krompiec, M.; Filapek, M.; Danikiewicz, W.; Kania, M.; Gębarowska, K.; Grudzka, I. Synthesis of 5-aminoisoxazolines from N-allyl compounds and nitrile oxides via tandem isomerization-1,3-dipolar cycloaddition. Tetrahedron 2010, 66, 5972-5981.

47. Krompiec, S.; Bujak, P.; Szczepankiewicz, W. Convenient synthesis of isoxazolines via tandem isomerization of allyl compounds to vinylic derivatives and 1,3-dipolar cycloaddition of nitrile oxides to the vinylic compounds. Tetrahedron Lett. 2008, 49, 6071-6074.

48. Krompiec, S.; Bujak, P.; Malarz, J.; Krompiec, M.; Skórka, Ł.; Pluta, T.; Danikiewicz, W.; Kania, M.; Kusz, J. An isomerization-1,3-dipolar cycloaddition tandem reaction towards the synthesis of 3-aryl-4-methyl-5- $O$-substituted isoxazolines from $O$-allyl compounds. Tetrahedron 2012, 68, 6018-6031. 
49. Iwakura, Y.; Shiraishi, S.; Akiyama, M.; Yuyama, M. Polymerizations by 1,3-Dipolar Cycloaddition Reactions. V. The 1,3-Dipolar Polycycloadditions of Dinitrile N-Oxides with Diolefins. Bull. Chem. Soc. Jpn. 1968, 41, 1648-1653.

50. Imgartinger, H.; Weber, A. Twofold cycloaddition of [60]fullerene to a bifunctional nitrile oxide. Tetrahedron Lett. 1996, 37, 4137-4140.

51. Dubrovskiy, A.V.; Jain, P.; Shi, F.; Lushington, G.H.; Santini, C.; Porubsky, P.; Larock, R.C. Solution-Phase Synthesis of a Diverse Library of Benzisoxazoles Utilizing the $[3+2]$ Cycloaddition of in Situ-Generated Nitrile Oxides and Arynes. ACS Comb. Sci. 2013, 15, 193-201.

52. Zhang, Y.; Wang, C.; Rothberg, L.; Ng, M.K. Surface-initiated growth ofconjugated polymersfor functionalization of electronically active nanoporous networks: synthesis, structure and optical properties. J. Mater. Chem. 2006, 16, 3721-3725.

53. Kreyes, A.; Amirkhani, M.; Lieberwirth, I.; Mauer, R.; Laquai, F.; Landfester, K.; Ziener, U. The Longest $\beta$-Unsubstituted Oligothiophenes and Their Self - Assembly in Solution. Chem. Mater. 2010, 22, 6453-6458.

54. Bumagin, N.A.; Kasatkin, A.N.; Beletskaya, I.P. Reactions of orgamnometallic compounds catalyzed by complexes of transition-Metals. 5. Organomagnesium, organozinc, organocadmium, and organoaluminum coumpounds in allyldemetallation reactions catalyzed by palladium complexes. B Acad. Sci. Ussr $\mathrm{CH}^{+}$1984, 33, 1696-1703.

55. Urbala, M.; Krompiec, S.; Penkala, M.; Danikiewicz, W. Solvent-Free Ru-catalyzed isomerization of allyloxyalcohols: Methods for highly selective synthesis of 1-propenyloxyalcohols. Appl. Catal. A Gen.2013, 451, 101-111.

56. Kuźnik, N.; Krompiec, S. Transition metal complexes as catalysts of double-Bond migration in O-allyl systems. Coord. Chem. Rev. 2007, 251, 222-233.

57. Chen, S.F.; Ho, E.; Mariano, P.S. A protodesilylation route for 2-Aza-1,3-diene synthesis. Tetrahedron 1988, 44, 7013-7026.

58. Govindan, C.K.; Taylor, G. Thermal electrocyclic reactions of 2-aza-1,3-butadiene derivatives. A new N-heterocyclic annelation. J. Org. Chem. 1983, 48, 5348-5354.

59. Grundmann, C.; Dean, J.M. Stable Aromatic Nitrile Oxides. J. Org. Chem.1965, 30, 2809-2812.

60. Liu, K.C.; Shelton, B.R.; Howe,R.K. A particularly convenient preparation of benzohydroximinoyl chlorides (nitrile oxide precursors). J. Org. Chem. 1980, 45, 3916-3918.

61. Benito-Lopez, F.; Egberink, R.J.M.; Reinhoudt, D.N.; Verboom, W. High pressure in organic chemistry on the way to miniaturization. Tetrahedron 2008, 64, 10023-10040.

62. Klärner, F.G.; Wurche, F. The Effect of Pressure on Organic Reactions. J. Prakt. Chem. 2000, 342, 609-636.

63. Fan, J.C.; Liang, J.; Wang, Y.; Shang, Z.C. Theoretical study of the mechanism of high-Pressure induced 1,3-dipolar cycloadditions of azides with electron-rich olefins. J. Mol. Struct. Theochem. 2007, 821, 145-152.

64. Gobis, K.; Foks, H.; Kędzia, A.; Wierzbowska, M.; Zwolska, Z. Synthesis and antibacterial activity of novel pyridine and pyrazine derivatives obtained from amidoximes. J. Heterocycl. Chem. 2009, $46,1271-1279$. 
65. Van der Peet, P.L.; Connell, T.U.; Gunawan, C.; White, J.M.; Donnelly, P.S.; Williams, S.J. A Click Chemistry Approach to 5,5'-Disubstituted-3,3'-Bisisoxazoles from Dichloroglyoxime and Alkynes: Luminescent Organometallic Iridium and Rhenium Bisisoxazole Complexes. J. Org. Chem. 2013, 78, 7298-7304.

66. Bianchi, L.; Dell'Erba, C.; Gasarrini, F.; Novi, M.; Patrillo, G.; Sancassan, F.; Tavani, C. Access to 5,5'-diaryl substituted 4,5,4',5'-tetrahydro[3,3']bi-isoxazolyl 2,2'-dioxides, 4,5,4',5'-tetrahydro[3,3'] bi-isoxazolyls and $\left[3,3^{\prime}\right]$ bi-isoxazolyls via an initial ring-opening of 3,4-dinitrothiophene. ARKIVOC 2002, 11, 124-129.

67. Chopade, P.R.; Louie, J. [2+2+2] Cycloaddition Reactions Catalyzed by Transition Metal Complexes. Adv. Synth. Catal. 2006, 348, 2307-2327.

68. Wu, Y.T.; Hayama, T.; Baldridge, K.K.; Linden, A.; Siegel, J.S. Synthesis of Fluoranthenes and Indenocorannulenes: Elucidation of Chiral Stereoisomers on the Basis of Static Molecular Bowls. J. Am. Chem. Soc. 2006, 128, 6870-6884.

69. Wu, Y.T.; Linden, A.; Siegel, J.S. Formal $[(2+2)+2]$ and $[(2+2)+(2+2)]$ Nonconjugated Dienediyne Cascade Cycloadditions. Org. Lett. 2005, 7, 4353-4355.

70. Tyagi, P.; Venkateswararan, P.T.A.; Thomas, K.R.J. Solution Processable Indoloquinoxaline Derivatives Containing Bulky Polyaromatic Hydrocarbons: Synthesis, Optical Spectra, and Electroluminescence. J. Org. Chem. 2011, 76, 4571-4581.

71. House, H.O.; Koepsell, D.G.; Campbell, W.J. Synthesis of some diphenyl and triphenyl derivatives of anthracene and naphthalene. J. Org. Chem. 1972, 37, 1003-1011.

72. Huang, X.; Zeng, L.; Zeng, Z.; Wu, J. Intramolecular Domino Electrophilic and Thermal Cyclization of peri-Ethynylene Naphthalene Oligomers. Chem. Eur. J. 2011, 17, 14907-14915.

73. Geng, Y.; Fechtenkötter, A.; Müllen, K. Star-like substituted hexaarylbenzenes: Synthesis and mesomorphic properties. J. Mater. Chem. 2001, 11, 1634-1641.

74. Bossenbroek, B.; Sanders, D.C.; Curry, H.M.; Shechter, H. Interactions and chemistry of 1,8-bis(phenylethynyl)naphthalene and 1,8-bis(1-alkynyl)naphthalenes. J. Am. Chem. Soc. 1969, 91, 371-379.

75. Wang, D.; Denux, D.; Riuz, J.; Astruc, D. The Clicked Pyridyl-Triazole Ligand: From Homogeneous to Robust, Recyclable Heterogeneous Mono- and Polymetallic Palladium Catalysts for Efficient Suzuki-Miyaura, Sonogashira, and Heck Reactions. Adv. Synth. Catal. 2013, 355, 129-142.

76. Bräse, S.; Gil, C.; Knepper, K.; Zimmermann, V. Organic Azides: An Exploding Diversity of a Unique Class of Compounds. Angew. Chem. Int. Ed. 2005, 44, 5188-5240.

77. Hein, J.E.; Fokin, V.V. Copper-catalyzedazide-alkynecycloaddition(CuAAC) and beyond: New reactivity of copper(I) acetylides. Chem. Soc. Rev. 2010, 39, 1302-1315.

78. Zhang, L.; Chen, X.; Xue, P.; Sun, H.H.Y.; Williams, I.D.; Sharpless, K.B.; Fokin, V.V.; Jia, G. Ruthenium-Catalyzed Cycloaddition of Alkynes and Organic Azides. J. Am. Chem. Soc. 2005, 127, 15998-15999.

79. Boren, B.C.; Narayan, S.; Rasmussen, L.K.; Zhang, L.; Zhao, H.; Lin, Z.; Jia, G.; Fokin, V.V. Ruthenium-Catalyzed Azide-Alkyne Cycloaddition: Scope and Mechanism. J. Am. Chem. Soc. 2008, 130, 8923-8930. 
80. Ni, B.B.; Wang, K.; Yan, Q.; Chen, H.; Ma, Y.; Zou, B. Pressure accelerated 1,3-dipolar cycloaddition of azide and alkyne groups in crystals. Chem. Commun. 2013, 49, 10130-10132.

81. Aufort, M.; Herscovici, J.; Bouhours, P.; Moreau, N.; Girard, C. Synthesis and antibiotic activity of a small molecules library of 1,2,3-triazole derivatives. Bioorg. Med. Chem. Lett. 2008, 18, 1195-1198.

82. Kramer, S.; Madsen, J.L.H.; Rottländer, M.; Skrydstrup, T. Access to 2,5-Diamidopyrroles and 2,5-Diamidofurans by $\mathrm{Au}(\mathrm{I})$-Catalyzed Double Hydroamination or Hydration of 1,3-Diynes. Org. Lett. 2010, 12, 2758-2761.

83. Nun, P.; Dupuy, S.; Gaillard, S.; Poater, A.; Cavallo, L.; Nolan, S.P. Gold(I)-catalyzed synthesis offuransandpyrrolesviaalkynehydration. Catal. Sci. Technol. 2011, 1, 58-61.

84. Duan, H.; Sengupta, S.; Petersen, J.L.; Akhmedov, N.G.; Shi, X. Triazole-Au(I) Complexes: A New Class of Catalysts with Improved Thermal Stability and Reactivity for Intermolecular Alkyne Hydroamination. J. Am. Chem. Soc. 2009, 131, 12100-12102.

85. Schulte, K.A.; Reisch, J.; Walker, H. Eine neue Pyrrolsynthese aus Butadiin-Derivaten. Chem. Ber. 1965, 98, 98-103.

86. Zheng, Q.; Hua, R. CuCl-catalyzed cycloaddition of 1,3-butadiynes with primary amines: An atom-economic process for synthesis of 1,2,5-trisubsituted pyrroles. Tetrahedron Lett. 2010, 51, 4512-4514.

87. Yang, C. Pyrrole-cored push-pull single chromophore. Tetrahedron Lett. 2010, 51, 2007-2009.

88. Kowada, T.; Kuwabara, T.; Ohe, K. Synthesis, Structures, and Optical Properties of Heteroarene-Fused Dispiro Compounds. J. Org. Chem. 2010, 75, 906-913.

89. Koyuncu, F.B.; Sefer, E.; Koyuncu, S.; Ozdemir, E. The New Branched Multielectrochromic Materials: Enhancing the Electrochromic Performance via Longer Side Alkyl Chain. Macromolecules 2011, 44, 8407-8414.

90. Severin, R.; Dove, S. The catalytic hydroamination of alkynes. Chem. Soc. Rev. 2007, 36, 1407-1420.

91. Paluch, M.; Sekuła, M.; Pawlus, S.; Rzoska, S.J.; Roland, C.M.; Zioło, J. Test of the Einstein-Debye Relation in Supercooled Dibutylphthalate at Pressures up to $1.4 \mathrm{GPa}$. Phys. Rev. Lett. 2003, 90, 175702-1-175702-4.

92. CrysAlis RED, Version 1.171.36.24; Oxford Diffraction Ltd. Agilent: Santa Clara, CA, USA, 2012.

93. Dolomanov, O.V.; Bourhis, L.J.; Gildea, R.J.; Howard, J.A.K.; Puschmann, H.J. OLEX2: A complete structure solution, refinement and analysis program. J. Appl. Crystallogr. 2009, 42, 339-341.

94. Sheldrick, G.M. A short history of SHELX. Acta Crystallogr. Sect. A 2008, 64, 112-122.

95. Block, E.; Tries, F.; He, C.; Guo, C.; Thiruvazhi, M.; Toscano, P.J. Perthio- and Perseleno-1,3butadienes, -but-1-ene-3-ynes, and -[3]-cumulenes: One-Step Syntheses from 1,4-Dilithio-1,3butadiyne. Org. Lett. 2003, 5, 1325-1327.

Sample Availability: Samples of the compounds (5)-(28) (except of compound 13a) are available from the authors.

(C) 2015 by the authors; licensee MDPI, Basel, Switzerland. This article is an open access article distributed under the terms and conditions of the Creative Commons Attribution license (http://creativecommons.org/licenses/by/4.0/). 